\title{
Boreal forest soil is a significant and diverse source of volatile organic compounds
}

\author{
Mäki, Mari
}

2019-08

Mäki , M , Aaltonen , H , Heinonsalo , J , Hellén , H , Pumpanen , J \& Bäck , J 2019 , ' Boreal forest soil is a significant and diverse source of volatile organic compounds ', Plant and Soil , vol. 441 , no. $1-2$, pp. 89-110 . https://doi.org/10.1007/s11104-019-04092-z

http://hdl.handle.net/10138/305404

https://doi.org/10.1007/s11104-019-04092-z

cc_by

publishedVersion

Downloaded from Helda, University of Helsinki institutional repository.

This is an electronic reprint of the original article.

This reprint may differ from the original in pagination and typographic detail.

Please cite the original version. 


\title{
Boreal forest soil is a significant and diverse source of volatile organic compounds
}

\author{
Mari Mäki $[$ Hermanni Aaltonen • \\ Jussi Heinonsalo • Heidi Hellén • Jukka Pumpanen • \\ Jaana Bäck
}

Received: 10 January 2019/Accepted: 11 April 2019/Published online: 24 May 2019

(C) The Author(s) 2019

\begin{abstract}
Aims Vegetation emissions of volatile organic compounds (VOCs) are intensively studied world-wide, because oxidation products of VOCs contribute to atmospheric processes. The overall aim of this study was to identify and quantify the VOCs that originate from boreal podzolized forest soil at different depths, in addition to studying the association of VOC concentrations with $\mathrm{VOC}$ and $\mathrm{CO}_{2}$ fluxes from the boreal forest floor.

Methods This is the first published study that measures belowground VOC concentrations at different depths in a podzol soil combined with simultaneous flux measurements from the boreal forest floor. The VOC
\end{abstract}

Responsible Editor: Feike A. Dijkstra.

Electronic supplementary material The online version of this article (https://doi.org/10.1007/s11104-019-04092-z) contains supplementary material, which is available to authorized users.

M. Mäki $(\bowtie) \cdot J$. Heinonsalo · J. Bäck

Institute for Atmospheric and Earth System Research / Forest

Sciences, 00560 Helsinki, Finland

e-mail: mari.maki@helsinki.fi

M. Mäki · J. Bäck

Faculty of Agriculture and Forestry, University of Helsinki, 00790 Helsinki, Finland

\section{H. Aaltonen · J. Heinonsalo · H. Hellén}

Finnish Meteorological Institute, 00560 Helsinki, Finland

J. Pumpanen

Department of Environmental and Biological Sciences, University of Eastern Finland, 70600 Kuopio, Finland concentrations were determined by sampling VOCs from air inside soil layers using the gas collectors and adsorbent tubes. Forest floor VOC fluxes were determined using a dynamic enclosure technique. All the VOC samples were analysed using a thermal desorption-gas chromatograph-mass spectrometer.

Results More than 50 VOCs, dominated by monoterpenes and sesquiterpenes, were detected in the air space in the soil during two measurement campaigns. The Ohorizon was a significant monoterpene source, because it contained fresh isoprenoid-rich litter. Belowground monoterpene concentrations were largely decoupled from forest floor monoterpene fluxes; thus, it seems that production processes and storages of VOCs partly differ from those VOCs that are simultaneously released from the forest floor. Both fluxes and concentrations of the monoterpenes and sesquiterpenes correlated with the $\mathrm{CO}_{2}$ fluxes in autumn, indicating that VOC release was driven by microbial activity.

Conclusions This is the first study where below-ground VOC concentrations were quantified in situ, and for this reason, this study provides valuable insights to the VOC sources present in soils.

Keywords Volatile organic compound - Boreal forest . Soil horizon $\cdot$ Flux $\cdot$ Litter

\section{Introduction}

Soil and understorey vegetation release volatile organic compounds (VOCs) from diverse storages and 
processes, including understorey vegetation, roots, decomposition processes, soil microbes, and vegetative litter concentrated in the O-horizon (Hayward et al. 2001; Smolander et al. 2006; Leff and Fierer 2008; Bäck et al. 2010; Aaltonen et al. 2011; Faubert et al. 2012; Mäki et al. 2017). The O-horizon may be a substantial source of VOCs, because higher monoterpene fluxes were measured from undisturbed soil in a Picea sitchensis forest than soil where the uppermost layer was removed (Hayward et al. 2001). VOCs such as mono- and sesquiterpenes are synthesised in primary metabolism and energy generation of microbes (Schulz and Dickschat 2007; Peñuelas et al. 2014; Yamanaka et al. 2015). Microbial decomposition processes of organic matter are also a significant VOC source (Gray et al. 2010). Soil $\mathrm{CO}_{2}$ release is dominated by root respiration and microbial decomposition (Davidson and Janssens 2006). $\mathrm{CO}_{2}$ uptake and respiration of ground vegetation is low in autumn (Kolari et al. 2009). For this reason, $\mathrm{CO}_{2}$ fluxes from soils may be used to monitor microbial activity in autumn.

Soil water content impacts upon the transport and diffusion of VOCs in soil and affects VOC release from vegetation (Skopp et al. 1990; Zhong et al. 2014; Svendsen et al. 2016). Soil water content also affects the decomposition of soil organic matter, may increase microbial VOC uptake in soil and impacts activity of different microbial groups (Davidson and Janssens 2006; Asensio et al. 2007b; Veres et al. 2014). VOC fluxes from the boreal forest floor are typically exponentially temperature-dependent (Mäki et al. 2017, 2019). For example monoterpene release from litter increases exponentially with temperature (Greenberg et al. 2012). The warming climate may increase microbial VOC synthesis, which is probably regulated by temperature-driven enzyme activity (Davidson and Janssens 2006). Warming may also change vegetation cover and affect the belowground VOC production of plants, which may almost double VOC fluxes from subarctic and arctic plants (Faubert et al. 2010; Kramshøj et al. 2016). Soil temperature and water content should be measured in parallel with belowground VOC concentrations and soil surface flux measurements to study how effectively VOCs from soils are released into the atmosphere from very complex structured podzol soils. VOCs such as methanol affects global budgets of hydroxyl radicals and ozone and after oxidized by $\mathrm{OH}$ radicals, $\mathrm{O}_{3}$ and $\mathrm{NO}_{3}$ radicals, oxidation products of isoprene, monoterpenes, and especially sesquiterpenes may form secondary organic aerosols (SOAs) (Jacob et al. 2005; Ziemann and Atkinson 2012).

Although the quantities and functions of compounds in soils are largely unknown, the VOCs in soils have also been suggested to have an effect on biological interactions as infochemicals by transmitting messages between soil organisms (Tholl et al. 2006; Schulz and Dickschat 2007; Insam and Seewald 2010; Wenke et al. 2010; Schenkel et al. 2018). VOCs may promote plant growth, control the nitrogen cycle, affect microbial metabolism and transmit long-distance communication between different decomposers (Insam and Seewald 2010; Asensio et al. 2012; Peñuelas et al. 2014; Tahir et al. 2017). A deeper understanding on the dynamics of soil processes and the roles of different soil components to VOC formation is needed (Asensio et al. 2007a; Leff and Fierer 2008; Gray et al. 2010; Rossabi et al. 2018). The wintertime dynamics of soil VOC production is especially interesting, as activity of the vegetation during the snow cover period is low, but the concentrations in soil and inside the snowpack may be quite high (Aaltonen et al. 2012). This is probably because snow and ice cover hinder diffusion of VOCs produced by microbial metabolism in snow pack, especially close to the soil surface.

Studies on belowground concentrations of VOCs are scarce (Lin et al. 2007), especially those in which measurements are made in situ. Earlier studies measured greenhouse gases such as $\mathrm{CO}_{2}$ and $\mathrm{CH}_{4}$ belowground routinely or presented results on soil VOC content, obtained by laboratory measurements from soil cores (Smolander et al. 2006; Pihlatie et al. 2007; Pumpanen et al. 2008; Leff and Fierer 2008; Asensio et al. 2008a; Gray et al. 2010). There is, however, no available established and well-evaluated method for measuring VOCs belowground, although it is also clear that previous experiments have significant limitations compared to measuring VOC exchange in undisturbed forest soil. Laboratory experiments allow the manipulation of environmental conditions, but cause severe disturbances to natural soil processes that may include the regulation and release of VOCs from damaged roots and interfere with the balance between the roots and soil microbial components. We have developed a method to collect VOC samples in situ from collectors installed belowground which equilibrate with the VOC concentration of the surrounding soil.

The overall aim of this study was to identify and quantify the VOC compounds that originate from boreal 
podzolized forest soil at different depths, in addition to studying the association of VOC concentrations with VOC and $\mathrm{CO}_{2}$ fluxes from the boreal soil surface. To determine the role of microbial activity in belowground VOC production and VOC release from the soil surface, we compared the relationship between forest floor $\mathrm{CO}_{2}$ and VOC fluxes and VOC concentrations of the different soil horizons.

Studies exist on the potentially high releases of VOCs from litter during biotic and abiotic processes and VOCs associated with multitrophic interactions between roots and microbes (Hayward et al. 2001; Isidorov and Jdanova 2002; Gray et al. 2010; Isidorov et al. 2010; Wenke et al. 2010; Ditengou et al. 2015; Schenkel et al. 2018). We hypothesized that belowground VOC concentrations are highest in the organic soil layer (the O-horizon) and the top mineral soil (the A-horizon) as the O-horizon contains isoprenoid-rich litter, and as fine roots and root-associated microbes are concentrated in the top horizon of the mineral soil. (2) The seasonal dynamics of belowground VOC concentrations and VOC fluxes from the soil surface differ, because the production processes, transport mechanisms and temperature and moisture conditions are different between soil and the soil surface. Greenberg et al. (2012) showed that temperature, moisture and labile carbon content explained VOC fluxes from decomposing litter. Microbial release and uptake are also affected by soil moisture (Asensio et al. 2007b; Bourtsoukidis et al. 2018). For this reason, we hypothesized that (3) soil temperature and soil water content may be used to explain belowground VOC synthesis i.e. belowground VOC concentrations.

\section{Material and methods}

Study site

The study was conducted in the southern boreal forest at the SMEAR II (Station for Measuring EcosystemAtmosphere Relations) station $\left(61^{\circ} 51^{\prime} \mathrm{N}, 24^{\circ} 17^{\prime} \mathrm{E}\right.$, $180 \mathrm{~m}$ a.s.l) in Hyytiälä (Juupajoki, Finland) (Hari and Kulmala 2005). The forest is a 58-yr-old (in 2019) Scots pine stand (Pinus sylvestris L.) with mean $\sim 18 \mathrm{~m}$ stand height and a tree density $\sim 1170 \mathrm{ha}^{-1}$ (Ilvesniemi et al. 2009). Below-canopy vegetation includes tree seedlings such as Sorbus aucuparia, Betula pendula and Picea abies and the dominating vascular plants in ground vegetation are Vaccinium myrtillus L., Vaccinum vitisidea L., Deschampsia flexuosa (L.) Trin., and Calluna vulgaris (L.) Hull. (Ilvesniemi et al. 2009; Aaltonen et al. 2011; Mäki et al. 2017). In addition, the soil is $33-60 \%$ covered by mosses such as Pleurozium schreberi, Dicranum sp., and Hylocomium splendens (Aaltonen et al. 2011). The soil above the homogeneous bedrock is Haplic podzol (FAO-UNESCO 1990) formed in a glacial till, with a depth range of $0.5-$ $0.7 \mathrm{~m}$ (Hari and Kulmala 2005). The total carbon (C) storage of the soil is $7 \mathrm{~kg} \mathrm{~m}^{-2}$ (Ilvesniemi et al. 2009). Frequent forest fires have an influence on soil $\mathrm{C}$ recovery and turnover time (Köster et al. 2014). The last occasion that the SMEAR II forest site burned was in 1962 (Mäki et al. 2017). The mean C content was highest in the organic soil horizon, O-horizon (356 $\mathrm{mg} \mathrm{g}^{-1}$ ), much lower in the eluvial soil horizon, A-horizon (32 $\left.\mathrm{mg} \mathrm{g}^{-1}\right)$ and lowest in the illuvial horizon, B-horizon $\left(24 \mathrm{mg} \mathrm{g}^{-1}\right)$ and in the parent material, C-horizon (5 $\mathrm{mg} \mathrm{g}^{-1}$ ) (see Supplementary Fig. 1), when the plots were established in 1995 (Pumpanen et al. 2008). The average nitrogen $(\mathrm{N})$ content is also highest in O-horizon $\left(13 \mathrm{mg} \mathrm{g}^{-1}\right)$ and decreases towards the deeper soil horizons $\left(\sim 1 \mathrm{mg} \mathrm{g}^{-1}\right)$ (Table 1$)$. The total surface area of the roots $<2 \mathrm{~mm}$ is $3.5 \mathrm{~m}^{2} \mathrm{~m}^{-2}$ in the $\mathrm{O}$ horizon, $1.8 \mathrm{~m}^{2} \mathrm{~m}^{-2}$ in the A-horizon and $0.8 \mathrm{~m}^{2} \mathrm{~m}^{-2}$ in the B-horizon (Ilvesniemi and Liu 2001). Total tree root biomass was $12,520 \mathrm{~kg} \mathrm{ha}^{-1}$ at the SMEAR II station (Ilvesniemi and Liu 2001). The long-term annual mean precipitation and the annual mean temperature at the SMEAR II station are $711 \mathrm{~mm}$ and $3.5^{\circ} \mathrm{C}$, respectively (Pirinen et al. 2012).

Soil VOC concentration measurements

VOC concentrations in different soil layers were measured in soil pits. Belowground VOC concentration measurements were conducted in the O-horizon and mineral soil layers in a boreal coniferous stand during two measurement campaigns from November 2008 to December 2011 and from April to December of 2016. Belowground VOC concentrations were also compared with forest floor VOC fluxes in 2016. Soil VOC concentration measurements were performed in different measurement pits in 2008-2011 and 2016. In 20082011, the measurements were carried out in the Ohorizon and B-horizon. New measurement pits where also the deepest soil layers were instrumented were constructed in 2014 because we wanted to measure 
Table 1 Physical characteristics of the measurement pits for the different soil horizons at the SMEAR II station in 1995

\begin{tabular}{|c|c|c|c|c|c|}
\hline \multirow[t]{2}{*}{ Horizon } & \multirow[t]{2}{*}{ Volume weight $\left(\mathrm{g} \mathrm{cm}^{-3}\right)$} & \multirow[t]{2}{*}{ Rocks (\% of weight) } & \multicolumn{3}{|c|}{ Particle size (\% of weight) } \\
\hline & & & clay & silt & sand \\
\hline \multicolumn{6}{|l|}{$\mathrm{O}$} \\
\hline $\mathrm{A}$ & 0.7 & 28.6 & 5.6 & 13.7 & 52.0 \\
\hline $\mathrm{B}$ & 0.9 & 27.7 & 6.7 & 13.0 & 52.6 \\
\hline $\mathrm{C}$ & 1.3 & 36.2 & 6.9 & 12.6 & 44.3 \\
\hline Horizon & $\mathrm{N}$-content $\left(\mathrm{mg} \mathrm{g}^{-1}\right)$ & C-content $\left(\mathrm{mg} \mathrm{g}^{-1}\right)$ & \multicolumn{3}{|l|}{$\mathrm{pH} \mathrm{CaCl} 2$} \\
\hline $\mathrm{O}$ & 13.5 & 355.7 & \multicolumn{3}{|l|}{3.4} \\
\hline $\mathrm{A}$ & 1.0 & 32.2 & \multicolumn{3}{|l|}{3.5} \\
\hline $\mathrm{B}$ & 1.1 & 23.5 & \multicolumn{3}{|l|}{4.4} \\
\hline $\mathrm{C}$ & 0.1 & 4.1 & \multicolumn{3}{|l|}{4.5} \\
\hline
\end{tabular}

Values are means of the measurements pits 1,4 , and 5

VOC concentrations through the whole soil profile including four different soil horizons with simultaneous soil water content and temperature measurements.

\section{Measurement set-up 2008-2011}

During the first campaign from 2008 to 2011, cylindrical gas collectors ( $4 \mathrm{~cm}$ in diameter, $12 \mathrm{~cm}$ long) were permanently installed in the three soil pits at two depths, 5 and $17 \mathrm{~cm}$ below the soil surface in May 2008 (Supplementary Fig. 1a). The upper collectors were installed in the O- horizon, and the lower collectors were completely embedded in the B-horizon (Supplementary Fig. 1a). The gas collectors were made of polytetrafluoroethylene (PTFE) by sintering, with pore sizes of $5-10 \mu \mathrm{m}$. The pores in the collectors allow the transport of gases through the membrane, while water is unable to percolate into the collector. Soil water content affects gas transport in soil and may also reallocate VOCs and organic matter within a soil profile. The collectors were connected to the two PTFE sampling lines ( $8 \mathrm{~mm}$ internal diameter) and further to the aboveground sampling system. Airtight Swagelok connectors made with stainless steel (Swagelok, Straight fitting, Union 10) were used to connect PTFE sampling lines to the aboveground sampling system. According to Ortega and Helmig (2008), teflon and stainless steel is used frequently with VOCs (e.g. in canister samplings, frames and tubings), because of the inertness of the materials. In the first measurement campaign, the measurements were performed during the period that started in November in 2008, continued from April to December in 2009, from July to November 2010, and from May to October in 2011. A total of 18 sampling events that provided 104 individual samples were carried out (Supplementary Table 2).

\section{Measurement set-up 2016}

For the second campaign conducted in 2016, the gas collectors were installed into four different soil horizons (O-horizon, A-horizon, B-horizon, and C-horizon) in five soil pits in 2011 (Supplementary Fig. 1b, Table 2, and Supplementary Table 1). The pits were carefully excavated and the soil horizons O-, A-, B- and C were kept separate. The collectors were installed horizontally towards the undisturbed soil in the excavated pits to minimize the excavation disturbance effect. After the installation, the soil layers were carefully placed back in the original order and compacted to the original volume of the soil. 10 -cm-long porous PTFE tubes $(8 \mathrm{~mm}$ internal diameter) were used as gas collectors (setup 2, Supplementary Fig. 1b). The porosity of the PTFE tube enabled the transport of the gases into the tubes. These collector tubes were covered with a stainless steel nets ( $2 \mathrm{~mm}$ mesh) to protect the tubing against physical damage. Sampling lines from the gas collectors to the aboveground VOC samplers were made of stainless steel tubing $(10 \mathrm{~mm}$ internal diameter). In the second measurement campaign, the measurements started on 21th of April 2016 and ended on 2nd of December of 2016. A total of 13 sampling events were carried out (Supplementary Table 2).

VOC soil sampling in 2008-2011 and in 2016

The samples from different soil horizons were collected by circulating air from the gas collectors 
through Tenax TA-Carbopack-B adsorbent (SigmaAldrich, Saint Louis, Missouri, USA) tubes $(6.3 \mathrm{~mm}$ $\mathrm{ED} \times 90 \mathrm{~mm}, 5.5 \mathrm{~mm}$ ID, Markes International, Llantrisant, UK) at flow rates of $100-150 \mathrm{ml} \mathrm{min}^{-1}$ using portable pumps. In each adsorbent tube, masses of Tenax TA and Carbopack-B adsorbents were $125 \mathrm{mg}$ and $125 \mathrm{mg}$. For avoiding artificial concentration fluxes during sampling, low flow rates were used and air pumped from the collectors through the adsorbent tubes was returned back to the collectors. Each sampling consisted of four 15min pumping periods, with 15 -min breaks between them, which enabled the VOC concentrations to equilibrate between the collectors and the soil around them. The total amount of VOCs in the air volume inside the collectors $(\sim 0.15 \mathrm{~L})$ alone would not have been sufficient for the analysis as this volume of sample was below the detection limit. For this reason, we sampled the air inside the collector for four 15-min periods, resulting the total sampling volume of 6-9 $\mathrm{L}$ for each adsorbent tube. Sampling capacity of the adsorbent tubes were tested and no breakthrough was observed for Tenax-TA/ Carbopack-B tubes, when sampling volume was $24 \mathrm{~L}$ including sampling time of four hours and a flow-rate of $100 \mathrm{ml} \mathrm{min}{ }^{-1}$ (Hellén et al. 2002), which is higher than 6-9 L sampling volumes that were used in this study. VOC concentration $\left(C_{\text {horizon }}, \mu \mathrm{g} \mathrm{m}^{-3}\right)$ of each soil horizon was calculated using Eq. (1):

$C_{\text {horizon }}=\frac{m_{\text {voc }}}{t_{\text {sampling }} F_{\text {sampling }}}$

where $m_{v o c}$ is the mass of each VOC $(\mu \mathrm{g})$ in the adsorbent tube, $t_{\text {sampling }}$ is the sampling time $(\mathrm{min})$ and $F_{\text {sampling }}$ is the flow rate of sampling $\left(\mathrm{m}^{3} \mathrm{~min}^{-1}\right)$.

\section{VOC and $\mathrm{CO}_{2}$ flux measurements}

VOC and $\mathrm{CO}_{2}$ flux measurements were measured on collars that were permanently installed on the soil surface to avoid disturbance on the soil during the measurements. One soil collar for VOC and $\mathrm{CO}_{2}$ flux measurements was placed next to $(20-50 \mathrm{~cm})$ each five VOC measurement pits (Table 2). Soil collars were placed in March 2016 and the measurements were started in April 2016. Isoprenoid and oxygenated VOC fluxes were measured using a dynamic enclosure chamber technique as described by
Table 2 Soil depth and ground vegetation coverage of the different measurement pits in 2016

\begin{tabular}{llllll}
\hline $\begin{array}{l}\text { Pit } \\
\begin{array}{l}\text { Soil } \\
\text { depth } \\
(\mathrm{cm})\end{array}\end{array}$ & $\begin{array}{l}\text { Ericoid } \\
\text { shrubs }(\%)\end{array}$ & $\begin{array}{l}\text { Mosses } \\
(\%)\end{array}$ & $\begin{array}{l}\text { Grasses } \\
(\%)\end{array}$ & $\begin{array}{l}\text { Non-vegetative } \\
\text { surface (\%) }\end{array}$ \\
\hline 1 & 50 & 25 & 10 & - & 65 \\
2 & 60 & 5 & - & 5 & 90 \\
3 & 80 & 25 & 20 & - & 55 \\
4 & 130 & 15 & 30 & 18 & 37 \\
5 & 160 & 7 & 2 & 8 & 83 \\
\hline
\end{tabular}

Soil depth is a vertical depth of the soil profile on top of the bedrock

Mäki et al. (2017). The headspace (height $40 \mathrm{~cm}$, chamber volume $10 \mathrm{~L}$ ) was a glass chamber placed for measurements on permanently installed soil collars (height $7 \mathrm{~cm}$, diameter $21.7 \mathrm{~cm}$ ). During the chamber enclosure, we continuously pumped $\left(11 \mathrm{~min}^{-1}\right)$ filtered (active carbon trap and $\mathrm{MnO} 2$-coated copper net) ambient air into the chamber headspace and flushed the chamber headspace for $30 \mathrm{~min}$ to equilibrate the measurement system before sampling. Samples from the incoming and outgoing air were taken for 1.5-2 $\mathrm{h}$ with two Tenax TA-Carboback-B adsorbent tubes (flow rate 0.1$\left.0.151 \mathrm{~min}^{-1}\right)$. We estimated the flux rate $(E, \mu \mathrm{g}$ $\mathrm{m}^{-2} \mathrm{~h}^{-1}$ ) of each VOC using Eq. (2):

$E=\left(C_{\text {out }}-C_{\text {in }}\right) \frac{F_{\text {chamber }}}{1000} \frac{60}{A}$,

where $C_{\text {in }}$ is the ingoing air concentration $\left(\mu \mathrm{g} \mathrm{m}^{-3}\right)$ and $C_{\text {out }}$ is the outgoing air concentration $\left(\mu \mathrm{g} \mathrm{m}^{-3}\right), F_{\text {chamber }}$ $\left(1 \mathrm{~min}^{-1}\right)$ is the flow rate of filtered air into the chamber headspace, and $A\left(\mathrm{~m}^{2}\right)$ is the soil surface area covered by the soil collar.

The fluxes of $\mathrm{CO}_{2}$ were determined using a dark static chamber technique (diameter $20 \mathrm{~cm}$ and height $30 \mathrm{~cm}$ ) whereby the concentration of $\mathrm{CO}_{2}$ in the closed chamber headspace was measured for 5 min using a GMP343 $\mathrm{CO}_{2}$ probe (Vaisala Oyj, Vantaa, Finland) and the $\mathrm{CO}_{2}$ efflux was calculated by linear fitting against time and $\mathrm{CO}_{2}$ concentration in the chamber headspace (Pumpanen et al. 2015).

Ambient air concentrations of monoterpenes (atomic mass unit 137) were measured about $20 \mathrm{~cm}$ above the soil surface from August to November in 2016 using the quadrupole proton transfer reaction mass spectrometer (quadrupole PTR-MS), just before 
the chamber headspace was closed for chamber flux measurements (Mäki et al. 2019).

Laboratory tests of the gas collectors

\section{Permeability test}

To determine the suitability of the method for soil gas analyses and the reliability of results, we performed a series of tests before installing the collectors in the soil. A permeability test was performed to monitor how fast VOCs permeate from the soil into the collector and to determine how fast VOC concentrations stabilize between the air inside and outside the collector (Supplementary Fig. 2). The effect of soil moisture was also evaluated by a permeability test. These results were used to determine the measurement and stabilization times. The permeability of the gas collectors for VOCs was determined in laboratory conditions before the installation in the field. The determinations were made for both dry collector and collector wetted with ultrapure water by using a gas mixture contained known concentrations of nine volatile compounds (methanol, acetonitrile, acetaldehyde, acetone, isoprene, methyl vinyl ketone, 2butanone, hexanal, and $\alpha$-pinene) and a proton transfer reaction-mass spectrometer (PTR-MS, Ionicon LTD, Austria) for on-line analysis (Supplementary Fig. 2). During the tests with wetted collector, there was a thin layer $(<1 \mathrm{~cm})$ of water in the bottom of the glass bottle where the collector was enclosed. The aim of the water layer was to humidify the dry airflow as well as to avoid the collector to dry out. The PTR-MS enabled fast response monitoring of the transport of VOC mixture and thus the determination of sampling time. The 15min break between individual samplings was used to stabilize VOC concentration between the gas collector and surrounding soil air.

\section{Recovery tests with soil layers}

A gas collector, a 10-cm-long piece of porous PTFE tube (setup 2), was tested in the laboratory (temperature $\sim 25{ }^{\circ} \mathrm{C}$ ) for measuring monoterpenes and sesquiterpenes (Supplementary Fig. 3). The gas collector tests were performed to show that our measurement system was able to provide robust results from the soil profile concentrations. The gas collector was tested in the Ohorizon to demonstrate the functioning of the gas collector in the natural, organic soil. In addition, the quartz sand soil was used to represent the mineral soil by excluding biological uptake and production of VOCs. The O-horizon was collected from forest in November and December 2018, and tested within $28 \mathrm{~h}$ to minimize the effect of biological VOC uptake and production on VOC concentrations during the gas collector test. Tests 1 and 2 were used to determine monoterpene concentrations of the gas collector from the O-horizon (test 1) and from the quartz sand soil (test 2) and test 3 to determine sesquiterpene concentrations of the gas collector from the O-horizon. In tests 1 and 2, a side flow $\left(0.21 \mathrm{~min}^{-1}\right)$ of air with known VOC concentrations was added into a main flow $\left(0.31 \mathrm{~min}^{-1}\right)$ of filtered (active carbon trap and $\mathrm{MnO} 2$-coated copper net) ambient air, which was continuously pumped into the test tank (Supplementary Fig. 3). In test 3, calibration solution with known VOC concentrations was injected with a syringe into a main flow $\left(0.51 \mathrm{~min}^{-1}\right)$ of filtered ambient air (Supplementary Fig. 3). We used this technique, because sesquiterpenes were not included into gas mixture that was used in tests 1 and 2.

A pressure relief tube from the measurement tank was used to avoid bias due to overpressure in the system. VOC-rich air was transported upwards with the air flow of $0.31 \mathrm{~min}^{-1}$ through the tested soil and VOC concentrations were measured from the soil using the gas collector. VOC concentrations were measured from the gas collector similarly as in the field measurements by circulating soil air through the same (Tenax TACarbopack-B) adsorbent tubes using a flow rate of $0.11 \mathrm{~min}^{-1}$. Four measurements were carried out from the quartz sand soil and three from the O-horizon. The VOC concentrations of the outgoing air of the tank were determined simultaneously during each gas collector measurement by sampling air into Tenax TACarbopack-B adsorbent tubes.

\section{Analytical methods}

The adsorbent tubes were analyzed in the laboratory, using a thermodesorption instrument (Perkin-Elmer TurboMatrix 650; PerkinElmer, Waltham, MA, USA) attached to a gas-chromatograph (Perkin-Elmer Clarus 600) with a mass-selective detector (Perkin-Elmer Clarus 600 T) (Aaltonen et al. 2011; Mäki et al. 2017). The sample tubes were desorbed at $300{ }^{\circ} \mathrm{C}$ for $5 \mathrm{~min}$, cryofocused in a Tenax cold trap $\left(-30^{\circ} \mathrm{C}\right)$ prior to injecting the compounds into the column by rapidly heating the cold trap $\left(40{ }^{\circ} \mathrm{C} \mathrm{min}^{-1}\right)$ to $300{ }^{\circ} \mathrm{C}$. The mass 
detector produced simultaneous full scan and singular ion monitoring. Four-point calibration standards in methanol solutions were used, except for the isoprene measurements for which we used one gaseous calibration standard (National Physical Laboratory, Teddington, UK). The standards were injected into the sampling tubes and the methanol was flushed away for $10 \mathrm{~min}$ before the analysis. The analytical variability was determined using replicate standard analysis. The detection limits varied from 0.0002 to $0.057 \mu \mathrm{g} \mathrm{m}^{-3}$ in concentration measurements and from 0.0005 to $1.477 \mu \mathrm{g} \mathrm{m}^{-2} \mathrm{~h}^{-1}$ in flux measurements (Supplementary Table 3). The VOC concentrations of isoprene, monoterpenes, sesquiterpenes and different oxygenated VOCs $\left(\mathrm{C}_{4}-\mathrm{C}_{15}\right.$ alcohols, carbonyls and acetates, methyl-2/3-furoates and $\alpha$-pinene oxide) were analyzed. The VOCs were identified by comparing their retention times and the mass spectras to the authentic standards. Calibration solutions for the sesquiterpenes, contained only longicyclene, isolongifolene, $\beta$-caryophyllene, $\alpha$ humulene, $\alpha$-gurjunene and $\beta$-farnesene. In 2016, other sesquiterpenes found in the samples were tentatively identified by comparing their mass spectra and retention indices to the NIST (the National Institute of Standards and Technology, Gaithersburg, Maryland, USA) mass spectral library and by retention time indexes. These sesquiterpenes were quantified as $\beta$-caryophyllene, isolongifolene, or longicyclene. One of the sesquiterpenes could not be tentatively identified and was therefore denoted as SQT1.

\section{Complementary data}

SMEAR II data from Avaa (https://avaa.tdata. fi/web/smart) was used as an ancillary dataset (Hari and Kulmala 2005). This dataset included soil temperatures and soil water content for each soil horizon from the same measurement pits, where VOC concentrations were measured in 2016. Soil temperature was measured by thermistors (Philips KTY81-110, Philips semiconductor, Eindhoven, the Netherlands) and soil water content with the TDR method (TDR 100, Campbell Scientific Inc., Logan, USA) in 2008-2011 and in 2016. Soil volumetric water content in the O-, A-, and B-horizon are means of five measurement pits and volumetric water content in the C-horizon is the mean of four measurement pits at the SMEAR II station. Precipitation was measured by an FD12P weather sensor (Vaisala Oyj, Helsinki, Finland). Soil surface coverages of ericoid shrubs, mosses, grasses, and non-vegetative surface were visually estimated for each soil $\mathrm{VOC} / \mathrm{CO}_{2}$-collar (Table 2).

\section{Calculations and statistical analyses}

Data analyses were performed with MATLAB software (version 2015a, MathWorks, Natick, MA, USA). The Kolmogorov-Smirnov and Shapiro-Wilkin tests were used to test the normality of the individual VOC concentrations for the O- and B-horizon (O-horizon $n=3$, and B-horizon $\mathrm{n}=3$ ) in 2008-2011 and for the different soil horizons (O-horizon $n=4$, A-horizon $n=5$, Bhorizon $\mathrm{n}=5$, and $\mathrm{C}$-horizon $\mathrm{n}=5$ ) in 2016. The amount of measurement pits was three in 2008-2011 and five in 2016. The amount of soil collars for VOC and $\mathrm{CO}_{2}$ flux measurements was also five in 2016. The Kolmogorov-Smirnov and Shapiro-Wilkin tests were also used for the total fluxes of monoterpene, sesquiterpene, oxygenated VOC fluxes, chamber temperature $\left({ }^{\circ} \mathrm{C}\right)$ and soil water content for each measurement pit (each pit and soil collar were measured 6-13 times in 2016). The non-parametric Kruskal-Wallis test ( $n=3$ in 2008-2011 and $\mathrm{n}=4-5$ in 2016, $\mathrm{df}=1$, significance level of $\left.p<0.100\left(^{\circ}\right), p<0.050, p<0.010, p<0.001\right)$ was used to determine whether the VOC concentrations of the soil horizons were statistically different from each other (Supplementary Table 4). The non-parametric Kruskal-Wallis test $(n=6-13, \mathrm{df}=1)$ was used for comparing the following flux parameters between the different soil pits: $\mathrm{CO}_{2}$, total monoterpene, total sesquiterpene, total oxygenated VOCs. The Kruskal-Wallis test was also used to compare chamber temperature, soil temperature and soil water content between the soil pits (Table 3). Exponential regression of the total monoterpene and sesquiterpene concentrations and soil temperature and water content were determined for the $\mathrm{O}$ - and B-horizons in 2008-2011 and for the O- and A-horizons in 2016 (Table 4). The Pearson correlation coefficient was used to test correlation between the total monoterpene and sesquiterpene fluxes and concentrations and between the $\mathrm{CO}_{2}$ flux and the total monoterpene and sesquiterpene concentrations (Supplementary Tables 5 and Table 7). The detection limit $\left(\mu \mathrm{g} \mathrm{m}^{-2} \mathrm{~h}^{-1}\right)$ of the VOC flux quantification (Supplementary Table 3 ) was calculated for each VOC compound and for all 13 samplings based on the equations that may be found in the publication by Mäki et al. (2017). The detection limit $\left(\mu \mathrm{g} \mathrm{m}^{-3}\right.$ ) of the VOC concentration quantification (Supplementary Table 3 ) for the soil horizon measurements 
Table 3 Forest floor VOC fluxes and environmental conditions of the measurement pits

\begin{tabular}{|c|c|c|c|c|c|c|c|c|}
\hline Pit & $\begin{array}{l}\text { Soil } \\
\text { depth cm }\end{array}$ & $\begin{array}{l}\text { Monoterpenes } \\
\mu \mathrm{g} \mathrm{m}^{-2} \mathrm{~h}^{-1}\end{array}$ & $\begin{array}{l}\text { Sesquiterpenes } \\
\mu \mathrm{g} \mathrm{m}^{-2} \mathrm{~h}^{-1}\end{array}$ & $\begin{array}{l}\text { OVOCs } \\
\mu \mathrm{g} \mathrm{m}^{-2} \mathrm{~h}^{-1}\end{array}$ & $\begin{array}{l}\mathrm{CO}_{2} \text { flux } \\
\mu \mathrm{g} \mathrm{m}^{-2} \mathrm{~h}^{-1}\end{array}$ & Chamber temperature $\mathrm{C}^{\circ}$ & Soil temperature $\mathrm{C}^{\circ}$ & $\begin{array}{l}\text { Soil water } \\
\text { content } \\
\mathrm{m}^{3} \mathrm{~m}^{-3}\end{array}$ \\
\hline 1 & 50 & $49.0^{\mathrm{a}}(31.5)$ & $4.6^{\mathrm{a}}(2.9)$ & $5.1^{\mathrm{a}}(3.9)$ & $0.15^{\mathrm{a}}(0.02)$ & $10.8^{\mathrm{a}}(2.2)$ & $8.3^{\mathrm{a}}(1.3)$ & $0.14^{\mathrm{a}}(0.01)$ \\
\hline 2 & 60 & $19.7^{\mathrm{a}}(6.9)$ & $6.3^{\mathrm{a}}(5.3)$ & $1.8^{\mathrm{a}}(0.6)$ & $0.13^{\mathrm{ac}}(0.04)$ & $11.1^{\mathrm{a}}(2.1)$ & $8.7^{\mathrm{a}}(1.5)$ & $0.12^{\mathrm{a}}(0.09)$ \\
\hline 3 & 80 & $20.7^{\mathrm{a}}(4.8)$ & $11.2^{\mathrm{a}}(10.9)$ & $0.6^{\mathrm{a}}(0.1)$ & $0.03^{\mathrm{b}}(0.02)$ & $9.3^{\mathrm{a}}(2.8)$ & $8.4^{\mathrm{a}}(1.3)$ & $0.34^{\mathrm{b}}(0.06)$ \\
\hline 4 & 130 & $26.1^{\mathrm{a}}(8.7)$ & $8.1^{\mathrm{a}}(7.6)$ & $0.6^{\mathrm{a}}(0.3)$ & $0.08^{\mathrm{c}}(0.01)$ & $10.4^{\mathrm{a}}(3.0)$ & $7.7^{\mathrm{a}}(1.5)$ & $0.30^{\mathrm{b}}(0.02)$ \\
\hline 5 & 160 & $61.9^{\mathrm{a}}(37.0)$ & $0.7^{\mathrm{a}}(0.3)$ & $1.0^{\mathrm{a}}(0.3)$ & $0.21^{\mathrm{a}}(0.07)$ & $12.2^{\mathrm{a}}(2.4)$ & $6.6^{\mathrm{a}}(1.2)$ & $0.78^{\mathrm{c}}(0.12)$ \\
\hline
\end{tabular}

Values are means (S.E.) of the whole dataset in 2016 (measurements were repeated 6-13 times in each pit). The differences in fluxes and environmental conditions between the measurement pits were tested with the Kruskal-Wallis test $\left(\mathrm{p}<0.05^{*}\right)$. Significant differences between the pits are indicated with different letters (Kruskal-Wallis test; $p<0.050$ ). Soil depth is a vertical depth of the soil profile on top of the bedrock

Table 4 Exponential relationship between the total monoterpene and sesquiterpene concentrations and soil temperature and water content from the O- and B-horizon in 2008-2011 and from the O and A horizons in 2016

\begin{tabular}{|c|c|c|c|c|c|c|c|c|}
\hline & & Horizon & $\mathrm{R}^{2}$ & $\mathrm{~N}$ & $\mathrm{p}$ & $\mathrm{R}^{2}$ & $\mathrm{~N}$ & $\mathrm{p}$ \\
\hline Season & Year & Soil temperature $\left({ }^{\circ} \mathrm{C}\right)$ & \multicolumn{3}{|c|}{ Monoterpene concentration $\left(\mu \mathrm{g} \mathrm{m}^{-2}\right)$} & \multicolumn{3}{|c|}{ Sesquiterpene concentration $\left(\mu \mathrm{g} \mathrm{m}^{-2}\right)$} \\
\hline April-June & 2008-2011 & $\mathrm{O}$ & 0.06 & 11 & 0.259 & & & \\
\hline July-September & 2008-2011 & $\mathrm{O}$ & 0.06 & 21 & $0.001 * * *$ & 0.00 & 21 & $0.004 * *$ \\
\hline October-December & 2008-2011 & $\mathrm{O}$ & 0.55 & 16 & $0.001 * * *$ & 0.00 & 10 & 0.128 \\
\hline April-June & 2008-2011 & $\mathrm{B}$ & 0.38 & 11 & $0.013 * *$ & & & \\
\hline July-September & 2008-2011 & B & 0.07 & 23 & $0.002 * *$ & 0.00 & 22 & 0.084 \\
\hline October-December & 2008-2011 & $\mathrm{B}$ & 0.09 & 16 & $0.018 * *$ & 0.01 & 11 & 0.390 \\
\hline April-June & 2016 & $\mathrm{O}$ & 0.15 & 10 & 0.164 & 0.07 & 9 & 0.140 \\
\hline July-September & 2016 & $\mathrm{O}$ & 0.28 & 13 & $0.043 *$ & 0.25 & 12 & $0.042 *$ \\
\hline October-December & 2016 & $\mathrm{O}$ & 0.00 & 17 & 0.222 & 0.11 & 17 & 0.136 \\
\hline April-June & 2016 & A & 0.00 & 16 & 0.283 & 0.01 & 16 & 0.321 \\
\hline July-September & 2016 & A & 0.74 & 19 & $0.001 * * *$ & & & \\
\hline October-December & 2016 & A & 0.01 & 23 & $0.026^{*}$ & 0.28 & 23 & $0.018^{*}$ \\
\hline Season & Year & $\begin{array}{l}\text { Soil water } \\
\quad \text { content }\left(\mathrm{m}^{3} \mathrm{~m}^{-3}\right)\end{array}$ & \multicolumn{3}{|c|}{ Monoterpene concentration $\left(\mu \mathrm{g} \mathrm{m}^{-2}\right.$ ) } & \multicolumn{3}{|c|}{ Sesquiterpene concentration $\left(\mu \mathrm{g} \mathrm{m}^{-2}\right)$} \\
\hline April-June & 2008-2011 & $\mathrm{O}$ & 0.07 & 11 & 0.246 & & & \\
\hline July-September & 2008-2011 & $\mathrm{O}$ & 0.05 & 21 & $0.001 * *$ & 0.00 & 21 & $0.004 * *$ \\
\hline October-December & 2008-2011 & $\mathrm{O}$ & 0.14 & 16 & $0.001 * *$ & 0.49 & 10 & $0.009 * *$ \\
\hline April-June & 2008-2011 & $\mathrm{B}$ & 0.26 & 11 & $0.030^{*}$ & & & \\
\hline July-September & 2008-2011 & $\mathrm{B}$ & 0.04 & 23 & $0.003 * *$ & 0.24 & 22 & $0.005 * *$ \\
\hline October-December & 2008-2011 & $\mathrm{B}$ & 0.06 & 16 & 0.023 & 0.50 & 11 & $0.018 *$ \\
\hline April-June & 2016 & $\mathrm{O}$ & 0.05 & 10 & 0.255 & 0.09 & 9 & 0.130 \\
\hline July-September & 2016 & $\mathrm{O}$ & 0.03 & 13 & 0.211 & 0.02 & 12 & 0.156 \\
\hline October-December & 2016 & $\mathrm{O}$ & & & & 0.03 & 17 & 0.259 \\
\hline April-June & 2016 & A & 0.07 & 16 & 0.179 & & & \\
\hline July-September & 2016 & A & 0.02 & 19 & 0.065 & 0.00 & 17 & 0.272 \\
\hline October-December & 2016 & $\mathrm{~A}$ & 0.11 & 23 & $0.008 * *$ & 0.13 & 23 & 0.129 \\
\hline
\end{tabular}

The significance level of $\mathrm{p}<0.1(\mathrm{o}), \mathrm{p}<0.05(*), \mathrm{p}<0.01(* *), \mathrm{p}<0.001(* * *))$ was used 
was calculated using the signal-to-noise ratio data obtained from the VOC quantification.

\section{Results}

The uncertainties of soil VOC concentration measurements

All the VOC standard compounds permeated the collector easily and the concentrations reached a constant level on the order of minutes (maximum $7 \mathrm{~min}$ ) in both the dry and wetted collectors (Fig. 1). $\alpha$-Pinene was the heaviest compound in the VOC gas mixture, and consequently its transport through the wall of the collector was the slowest of the VOCs measured. In contrast, methanol peaked immediately after introducing the gas mixture into the glass bottle, but after that it stabilised quickly. Based on these stabilization times, we assumed that stabilization of sesquiterpenes would take even longer since they are heavier than monoterpenes, thus the 15-min break time was chosen.

In addition to permeability tests, we conducted laboratory tests with gas collectors installed inside the soil layers and flushed the soil with known monoand sesquiterpene concentrations. The O-horizon collector reproduced $55 \%( \pm 14 \%)$ and $68 \%( \pm 19)$ of the mono- and sesquiterpene concentrations coming out from the soil. The recovery reflects the gas collector response. To verify the biological contribution in the O-horizon, quartz sand was also tested. In quartz sand, the collector also reproduced $55 \%( \pm 23 \%)$ of the monoterpene concentrations coming out from the soil. Results indicate that recoveries of the gas collectors are in acceptable levels, as the collectors reproduced $55 \%$ of the monoterpene concentrations coming out from the soil, but the concentrations measured by this method are underestimations. Considering the reactivity of monoterpenes and especially sesquiterpenes, the recovery rate of $100 \%$ would be very difficult to reach and for this reason, the recovery rate of $55 \%$ is a relatively good result.

Belowground vertical gradients of VOC concentrations in 2016

Over 50 different VOCs were detected in the soil air during the two measurement campaigns and concentrations were dominated by monoterpenes. Belowground VOC concentrations in the different soil horizons were compared (Fig. 2). The mean of the total monoterpene concentrations was highest in the O-horizon $\left(332 \mu \mathrm{g} \mathrm{m}^{-3}\right)$, lower in the A-horizon $\left(87 \mu \mathrm{g} \mathrm{m}^{-3}\right.$, $p>0.1$, although the difference was not statistically significant, and significantly smaller in the lower horizons (B-horizon $133 \mu \mathrm{g} \mathrm{m}^{-3}, p<0.001$ and C-horizon $11 \mu \mathrm{g} \mathrm{m}^{-3}, \mathrm{p}<0.001$ ) (Supplementary Table 4). However, total sesquiterpene and total oxygenated VOC (OVOC) concentration means were highest in the Ahorizon (13 and $7 \mu \mathrm{g} \mathrm{m}^{-3}$, respectively), although statistically significant differences between soil horizons could not be observed for the total sesquiterpenes or for

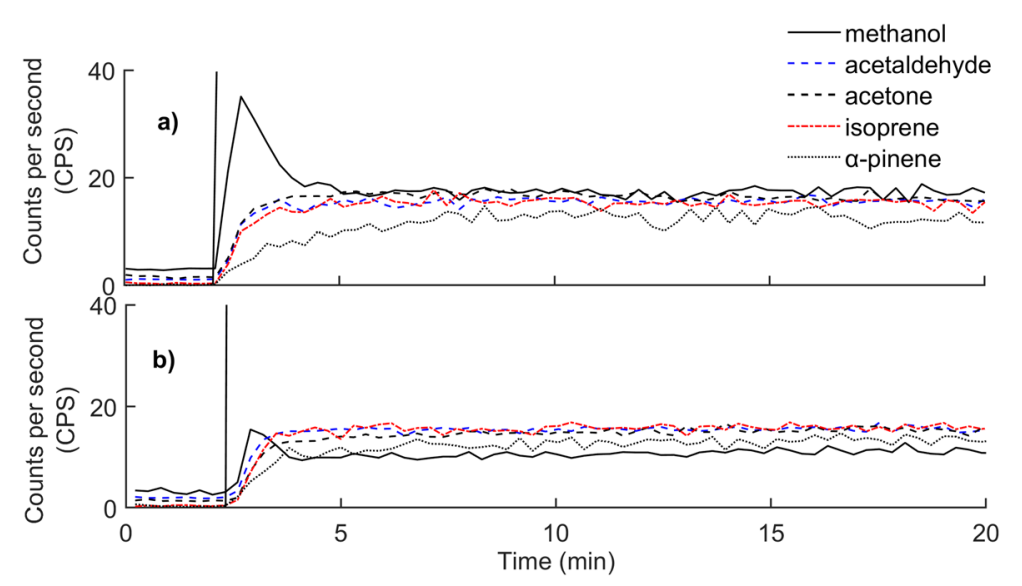

Fig. 1 Results of the permeability tests of the PTFE collector with the five VOCs. A permeability test was used to monitor how fast VOCs permeate into the gas collector and to determine how fast VOC concentrations stabilize between the air inside and outside the collector. Panel a) shows the results with dry collector and panel b) with a wetted collector. Vertical line shows the time point when the introduction of the VOC standard began 

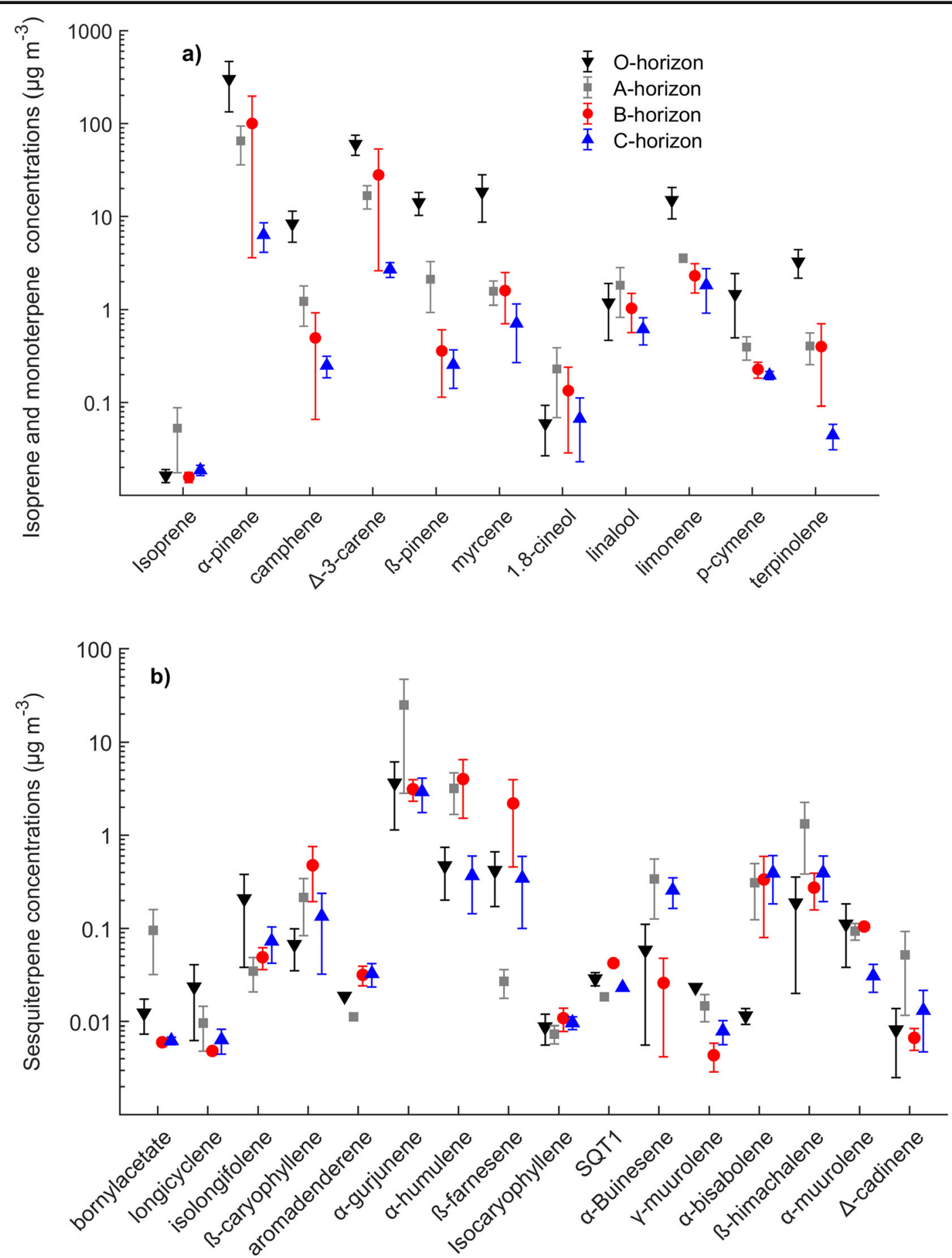

Fig. 2 Isoprene and individual monoterpene (a) and sesquiterpene (b) concentrations $\left(\mu \mathrm{g} \mathrm{m}^{-3}\right)$ from the different soil horizons $(\mathrm{O}(\mathrm{N}=4), \mathrm{A}(\mathrm{N}=5), \mathrm{B}(\mathrm{N}=5)$, and $\mathrm{C}(\mathrm{N}=5))$ in 2016.
Concentrations are means and error bars are standard error of the whole data for each soil horizon. SQT1 was not identified the total oxygenated VOCs (Supplementary Table 4). Sesquiterpenes and OVOCs are two very diverse groups of chemical compounds in which some compounds occurred in the highest concentrations in the O-horizon 
and other compounds in the A-horizon (Fig. 2, Supplementary Table 4). There were no differences in VOC concentrations between the soil pits (data not shown).

Belowground VOC concentrations and VOC fluxes from the soil surface in 2016

Total monoterpene concentrations in the O-horizon were highest in late summer (28.7. and 24.8.) and in December (1.12.), when the soils were under snow cover, although the differences were not statistically significant (Fig. 3). The mean temperature was $5.9^{\circ} \mathrm{C}$. There was some snow on the ground in November and permanent snow cover in December, but no snow remained in April, when measurements commenced. Monoterpene concentrations in mineral soil (Ahorizon) were generally higher in spring and summer (22.4-24.8) and decreased towards autumn except in December (1.12.), when concentrations suddenly increased, although the differences were not statistically significant (Fig. 3). In general, there seemed to be a clear trend that belowground concentrations were exceptionally high in December under snow cover. Total sesquiterpene concentrations in the A-horizon were highest in spring (22.4. and 17.5.), in late summer (24.8.), and in October (1.10.), although the differences were mainly statistically insignificant (Fig. 3). There was no clear seasonal variation in the O-horizon, except in October and in December when the concentrations suddenly increased in the whole soil profile (Fig. 3). Isoprene concentrations peaked in the A-horizon in April (22.4.) and early October (1.10.) and the differences were statistically significant $(p<0.1)$, except in early June (3.6.) and late July (28.7.) (Fig. 3).

The total monoterpene fluxes were highest in October (1.10.) $(p<0.1$, except 22.4. $p>0.1)$ and lowest in late summer (24.8.) $(\mathrm{p}<0.1$, except 3.6. and 1.12. $\mathrm{p}>$ 0.1 , whereas the total sesquiterpene fluxes were highest in spring (22.4. and 3.6. $\mathrm{p}<0.1$, except 24.8. and 3.10. $\mathrm{p}>0.1$ ) (Fig. 3). The total monoterpene flux varied between $19.7-61.9 \mu \mathrm{g} \mathrm{m}^{-2} \mathrm{~h}^{-1}$, the total sesquiterpene flux between $0.7-11.2 \mu \mathrm{g} \mathrm{m}^{-2} \mathrm{~h}^{-1}$, and the total oxygenated VOC flux between $0.6-5.1 \mu \mathrm{g} \mathrm{m}^{-2} \mathrm{~h}^{-1}$ in 2016 (Table 3 ). There were no statistically significant differences in VOC fluxes between measurement pits within the different VOC groups. The $\mathrm{CO}_{2}$ flux was lower (0.03-0.08 $\mathrm{mg} \mathrm{m}^{-2} \mathrm{~s}^{-1}$ ) when understorey vegetation cover was high (45-63\%) and $\mathrm{CO}_{2}$ flux increased $\left(0.13-0.21 \mathrm{mg} \mathrm{m}^{-2} \mathrm{~s}^{-1}\right)$ when the understorey vegetation cover was low (10-35\%) (Table 3).

The belowground vertical concentration profiles were not coupled to observed forest floor flux rates, when the whole data were combined. In the individual pits, the total monoterpene flux correlated with the Ohorizon concentration in pit four $(\mathrm{r}=0.78, p<0.05)$ and with the A-horizon in pit five $(r=0.83, p<0.050)$ (Supplementary Table 5). The total sesquiterpene flux also correlated with concentrations of the O-horizon $(\mathrm{r}=$ $0.62, \mathrm{p}<0.050)$ and of the A-horizon $(\mathrm{r}=0.72$, $p<0.010$ ) in pit three (Supplementary Table 5). Sesquiterpene concentrations were decoupled from soil surface fluxes (Fig. 3). The total monoterpene fluxes were explained by chamber temperature from summer $\left(\mathrm{R}^{2}=\right.$ $0.34, p<0.001)$ to autumn $\left(\mathrm{R}^{2}=0.48, \mathrm{p}<0.001\right)$ and by the $\mathrm{CO}_{2}$ flux in summer $\left(\mathrm{R}^{2}=0.23, \mathrm{p}<0.001\right)$ and autumn $\left(R^{2}=0.93, p<0.001\right)$ (Supplementary Table 6). The total sesquiterpene fluxes were explained by chamber temperature in spring $\left(\mathrm{R}^{2}=0.74, \mathrm{p}<0.001\right)$ and by the $\mathrm{CO}_{2}$ flux from spring $\left(\mathrm{R}^{2}=0.52, \mathrm{p}<0.01\right)$ to summer $\left(\mathrm{R}^{2}=0.21, \mathrm{p}<0.05\right)$ (Supplementary Table 6). There was no exponential relationship between the total monoterpene and sesquiterpene fluxes and soil water content (data not shown). The total monoterpene concentration in the A-horizon correlated with the $\mathrm{CO}_{2}$ flux in autumn $(r=0.76, p<0.01)$ (Supplementary Table 7). There was also a correlation between the total sesquiterpene concentration in the O-horizon and the $\mathrm{CO}_{2}$ flux in autumn $(\mathrm{r}=0.68, \mathrm{p}<0.05)($ Supplementary Table 7).

The belowground vertical monoterpene concentrations were also uncoupled to the ambient air concentrations measured about $20 \mathrm{~cm}$ above the soil surface using the proton-transfer reaction massspectrometer (quadrupole-PTR-MS) from August to November in 2016 (Fig. 4). The ambient air concentrations were $0.3 \%$ to $17 \%$ of the monoterpene concentrations in the O-horizon.

Soil temperature and water content impact on VOC concentrations, 2008-2011 and 2016

There was a statistically significant relationship between the total monoterpene concentration and soil temperature in the O-horizon in autumn $\left(\mathrm{R}^{2}=0.55 \mathrm{p}<0.001\right)$ and in the B-horizon in spring $\left(\mathrm{R}^{2}=0.38, \mathrm{p}<0.01\right)$ and between the total sesquiterpene concentration and soil water content in the O-horizon in autumn $\left(\mathrm{R}^{2}=0.49, \mathrm{p}\right.$ $<0.01$ ) from 2008 to 2011 (Table 4). However, 
Fig. 3 The mean a) isoprene, b) monoterpene, and c) sesquiterpene fluxes $\left(\mu \mathrm{g} \mathrm{m}^{-2} \mathrm{~h}^{-1}\right)$ from the forest floor and concentration $\left(\mu \mathrm{g} \mathrm{m}^{-3}\right)$ from the O- and A-horizon from April to December in 2016. Error bars are standard error of the four $(\mathrm{O}-$ horizon) or five (A-horizon) gas collectors
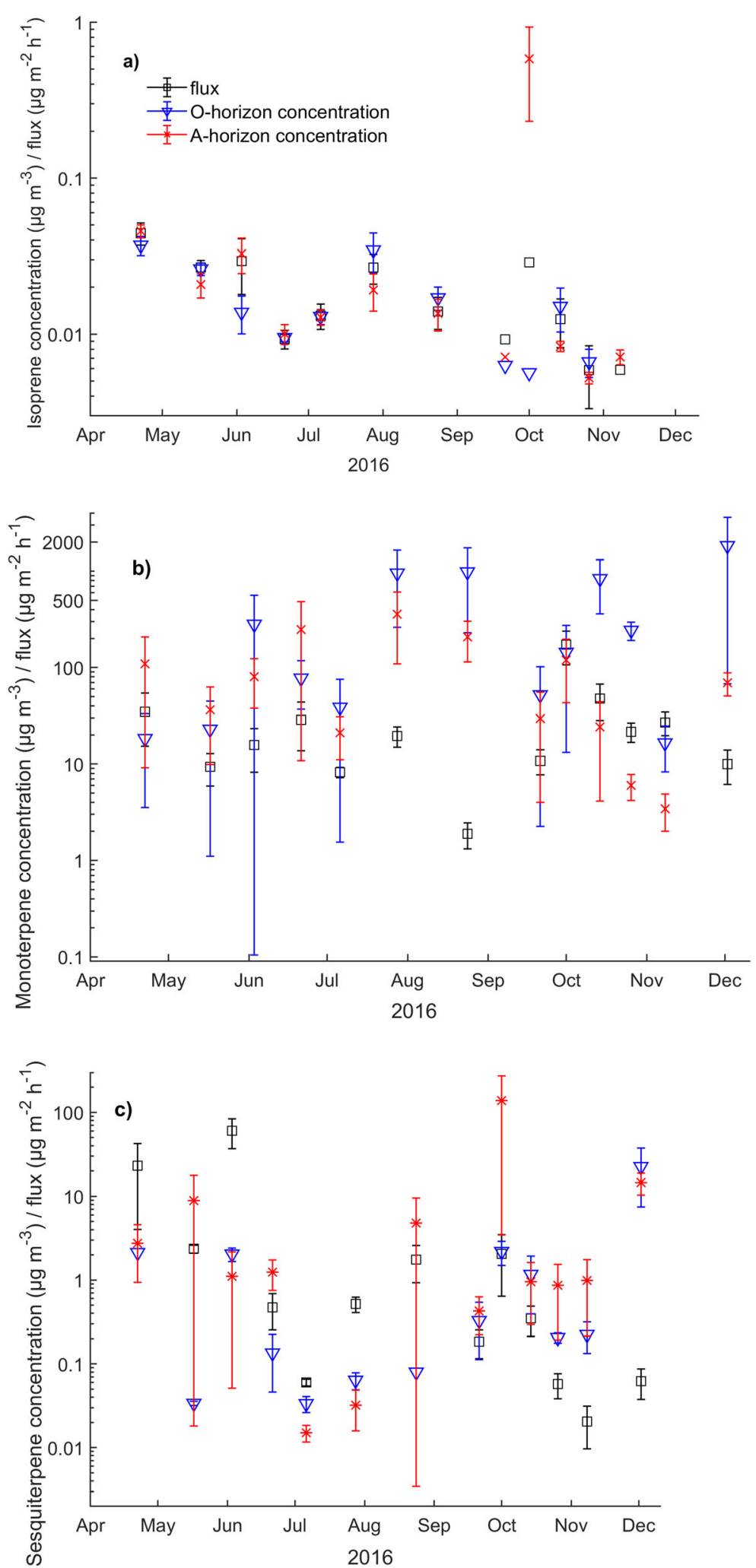
Fig. 4 The mean monoterpene concentration $\left(\mu \mathrm{g} \mathrm{m}^{-3}\right)$ from the $\mathrm{O}$ - and A-horizon and from the ambient air from August to December in 2016. Error bars are standard error of the four $(\mathrm{O}$ horizon) or five (A-horizon) gas collectors. Error bars of ambient air measurements are based on two measurement locations at the SMEAR II station

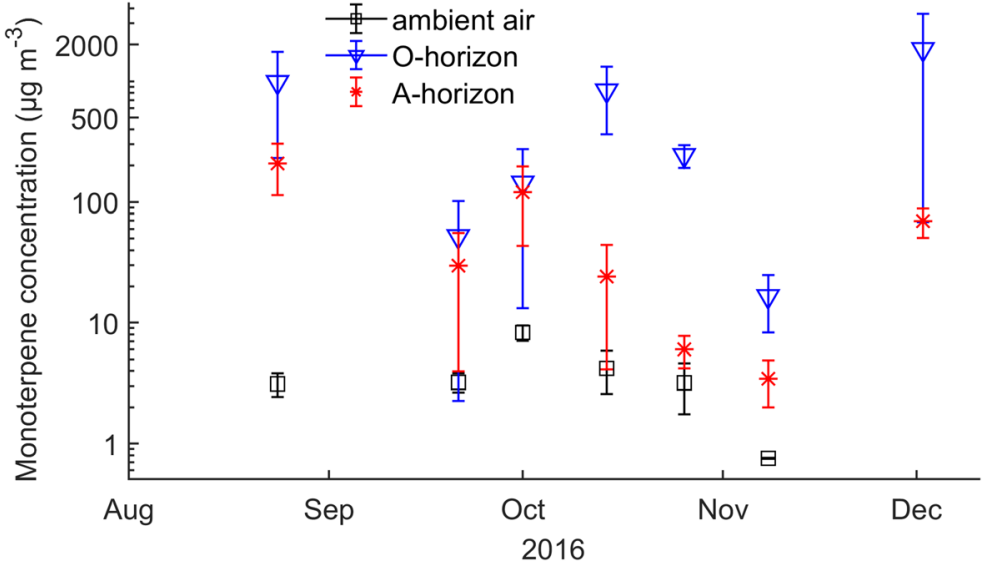

observable except in the year 2009, when fluxes were highest in the O-horizon in August and in the B-horizon in September. There was no clear seasonal variation for isoprene. The spatial variation in belowground isoprenoid concentrations between the three measurement pits was substantial. Statistically significant differences between the O-horizon and the mineral soil were not obtained for any major compound or compound group.

\section{Discussion}

VOC concentrations reflect the biological and physico-chemical properties of soil horizons

Our results clearly show that monoterpene concentrations are highest in the O-horizon. Podzol soil surface is formed by fresh vegetative litter that contains easily decomposable glucose, starch and cellulose, and very slow-decomposable organic matter (Beyer 1996; Prescott et al. 2000; Prescott 2010). The concentrations of $\alpha$-pinene, camphene, $\beta$-pinene, myrcene, and limonene were highest in the O-horizon. Terpene concentrations were also found to be higher in samples of litter and the organic soil layer compared to the mineral soil layer (Asensio et al. 2008b). Monoterpene concentrations and fluxes from the O-horizon are probably driven by the monoterpene-rich litter, in which the decomposition processes are regulated by litter quantity and quality, climate and soil microbial populations (Prescott et al. 2000). Both fluxes and concentrations of the monoterpenes and sesquiterpenes correlated with the $\mathrm{CO}_{2}$ flux in autumn, which 
Fig. 5 The monthly mean monoterpene concentration $\left(\mu \mathrm{g} \mathrm{m}^{-3}\right)$ and soil temperature $\left(\mathrm{C}^{\circ}\right)$ for the O-horizon and the $\mathrm{B}$ horizon during the summer months in 2009-2011. Error bars are standard error of the three gas collectors

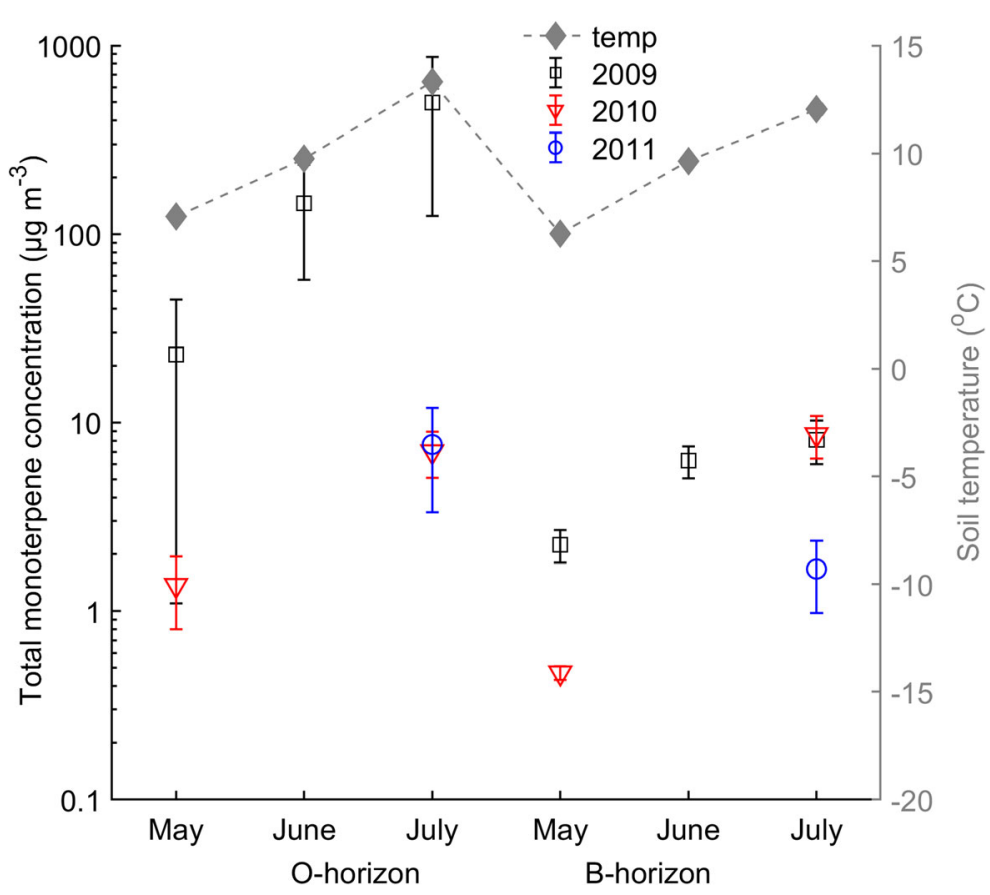

indicates that VOC production was driven by microbial activity (heterotrophic consumption). The decomposing litter has been assumed to be the main source for VOCs in the forest floor (Hayward et al. 2001; Leff and Fierer 2008; Mäki et al. 2017). It is evident that both decomposers and the decomposing material affect the formation of VOCs, and also that VOCs released through the decomposition processes are probably dependent on the litter type (Gray et al. 2010). Microbes are most active in the O-horizon, which contains easily available carbon for their metabolism (Makkonen and Helmisaari 1998; Leff and Fierer 2008; Pumpanen et al. 2008). Organic carbon and nitrogen availability is typically higher in the Ohorizon than in mineral soil (Parmelee et al. 1993; Deluca and Boisvenue 2012). Soil properties also explain high monoterpene concentrations in the Ohorizon. Soil porosity is higher in the O-horizon compared to the A-horizon, which means that the gas transport is faster in the O-horizon compared to the A-horizon. The effect of rainfall moving downwards and transporting VOCs towards deeper soil layers is likely stronger in the O-horizon.

Soil microbial community composition is determined by the carbon nitrogen ratio $(\mathrm{C}: \mathrm{N})$ ratio, $\mathrm{pH}$ and tree cover (Högberg et al. 2007). A low $\mathrm{pH}$ favours fungi as the main decomposers over bacteria in boreal coniferous forest soils (Alexander 1977). However, sequencing revealed that the dominating groups of bacteria in humus are Acidobacteria, Proteobacteria, and Actinobacteria (Timonen et al. 2017). Importance of bacteria for VOC release from decomposing litter may be effected by litter type (Svendsen et al. 2018). The individual sources of VOCs are very difficult to determine under field measurement conditions, but laboratory experiments show the capability of soil fungi to produce and release numerous volatile compounds (Bäck et al. 2010; Müller et al. 2013). Roots of trees and perennial shrubs are also an important belowground VOC source (Smolander et al. 2006; Lin et al. 2007). Their uneven coverage also causes spatial variation among the concentration measurements. Detectable isoprene concentrations belowground were surprising because isoprene is known to be produced in photosynthetic tissues, and production is strongly light dependent without storages in plant cells (Monson and Fall 1989; Delwiche and Sharkey 1993; Sharkey and Singsaas 1995). However, laboratory measurements have indicated that isoprene may also be produced by fungi and by needle litter during decomposition (Bäck et al. 2010; Gray et al. 2010).

High monoterpene and sesquiterpene concentrations were also detected in the A-horizon, which contains the bulk of roots and most of the root-associated microbes. 


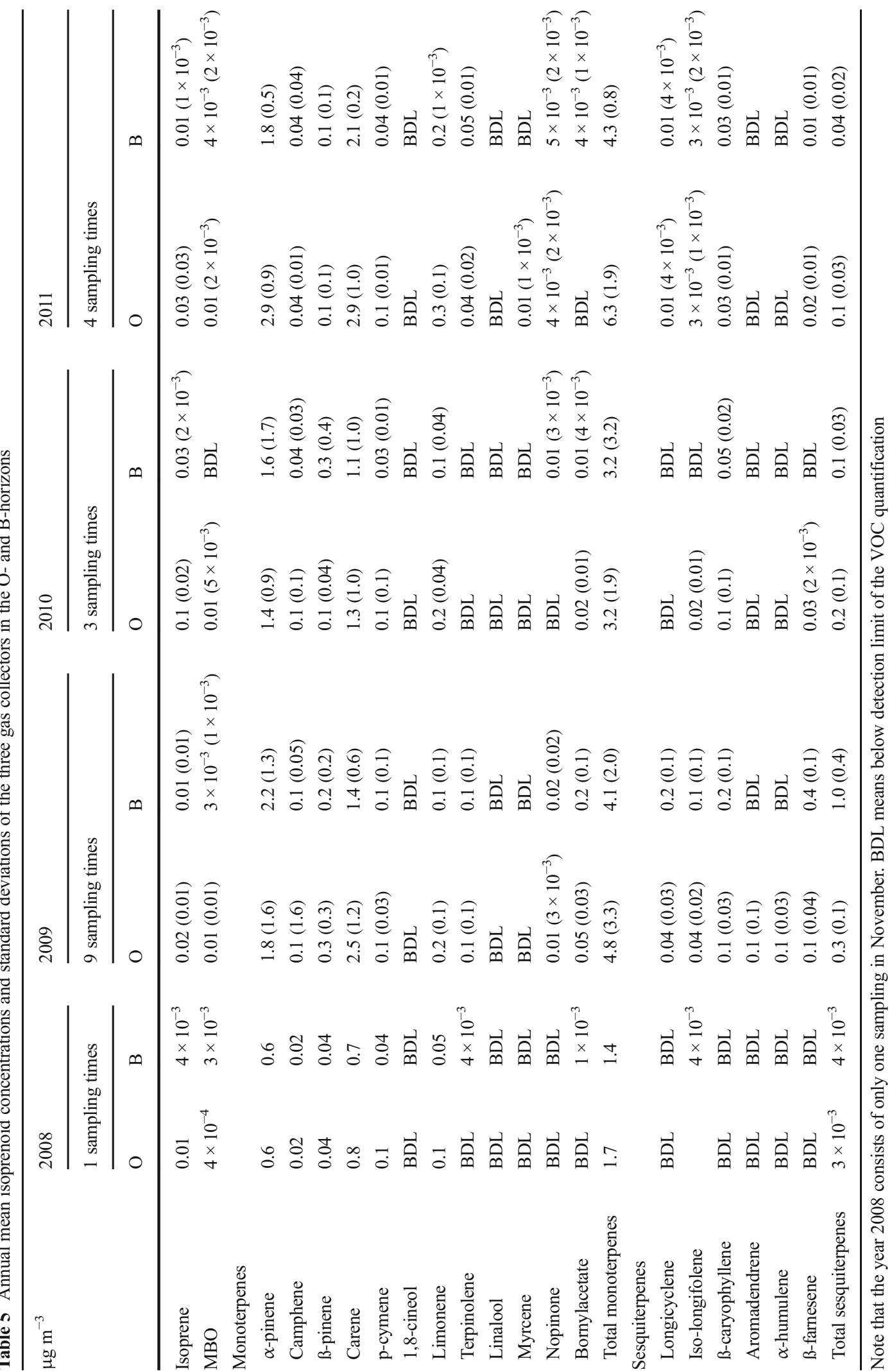


Our results indicated that sesquiterpene production (bornylacetate, $\alpha$-gurjunene, $\alpha$-humulene, and $\beta$ himachalene) is not linked to the storages in plant litter, but rather to roots and the root-associated microbes which are most abundant/active in the A-horizon. VOCs are widely used in soils as defence and communication infochemicals between soil organisms (Insam and Seewald 2010; Schulz and Dickschat 2007; Peñuelas et al. 2014; Ditengou et al. 2015; Schenkel et al. 2018). The carbon content and nitrogen content decrease with increasing soil depth (Table 1). Microbial activity and biomass have also been found to decrease with depth (Taylor et al. 2002; Fierer et al. 2003, which likely explains why VOC concentrations were the highest in the O- and A-horizon and the lowest in the B- and Chorizon. The VOCs in mineral soil may be related to the living roots or decaying root-litter. Monoterpene fluxes from the root-soil interface may be quantitatively and qualitatively different from those released by dead roots (Lin et al. 2007), which may cause variation in VOC concentrations between the soil horizons. Sesquiterpene concentrations were quite homogeneous between soil horizons, which indicates that sources for sesquiterpenes are more stable and possibly also relatively independent of environmental factors. Sesquiterpenes measured under laboratory conditions are produced by endophytes, decomposers and ectomycorrhizal fungi (Bäck et al. 2010; Rösecke et al. 2000; Ditengou et al. 2015; Weikl et al. 2016). The low volatility and high reactivity of sesquiterpenes may result in much higher concentrations near the sources than average concentrations in the soil horizon. Quantified sesquiterpene concentrations may be underestimated, because the Ohorizon is a highly porous media and sesquiterpenes as highly reactive compounds may be converted into other compounds by chemical reactions with soil air oxidants. A lack of pure standards also increased the uncertainty of certain sesquiterpene (SQT1, $\alpha$-buinesene, $\gamma$ muurolene, $\alpha$-bisabolene, $\beta$-himachalene, $\alpha$ muurolene, $\Delta$-cadinene) analyses.

Our results show moderate correlation between isoprenoid concentrations and soil temperature, which was expected as biological and physico-chemical processes such as diffusion and volatility are directly influenced by temperature (Peñuelas and Staudt 2010). Moreover, enzyme activity of microbial metabolism that lead to the VOC production is affected by temperature (Mancuso et al. 2015). The results also showed negative correlations between the soil water content and the monoterpene concentrations, although the correlation was not significant. Transport of gases may be effectively prevented by water, which blocks the micropores in the soil in wet weather or poorly drained soils. In sandy soils, water movement downward from the O-horizon is usually efficient and this may also transport water soluble OVOCs (verbenone, 1-butanol, isopropanol, 2-butanone, 1-hexanol and cis-3-hexenyl acetate, and slightly water-soluble methyl-12-furoate, 1-penten-3-ol, 1-pentanol, butyl acetate, trans-3-hexen-1-ol, trans-2-hexen-1-ol, and $\alpha$-pinene oxide) into the mineral soil and reduce the differences in VOC concentrations between the Ohorizon and mineral soil horizons. Soil water content was high in the $\mathrm{C}$-horizon, which led to the high humidity in the adsorbent tubes and consequently some samples (pits 4 and 5) could not be analyzed using the thermal desorption-gas chromatographymass spectrometry method. It may be assumed that concentrations would have been relatively low, as low oxygen availability slows down aerobic decomposition, but enables slower and less effective anaerobic decomposition (Davidson and Janssens 2006).

The soil concentrations were mostly decoupled from forest floor VOC fluxes, which indicates that belowground sources are different from those that release VOCs from the soil surface. Most of the measured fluxes at the forest floor level probably originated from understorey vegetation and the decomposing O-horizon, humus (Hewitt and Street 1992; Aaltonen et al. 2011; Faubert et al. 2012; Rinnan et al. 2014). Total monoterpene flux rates (21-62 $\mathrm{g} \mathrm{m} \mathrm{m}^{-2} \mathrm{~h}^{-1}$ ) from the boreal forest floor were the same order of magnitude than from the same forest site in $2015\left(23 \mu \mathrm{g} \mathrm{m} \mathrm{m}^{-2} \mathrm{~h}^{-1}\right.$, Mäki et al. 2017). The individual flux rates of monoterpenes such as $\alpha$-pinene $\left(0-14 \mu \mathrm{g} \mathrm{m}^{-2} \mathrm{~h}^{-1}\right)$ and $\Delta$-3-carene $\left(0-6 \mu \mathrm{g} \mathrm{m}^{-2} \mathrm{~h}^{-1}\right)$ measured in 2008 were also comparable to our study (Aaltonen et al. 2011). The forest floor vegetation also absorbs VOCs on moist leaf surfaces, which creates a bidirectional flux especially under moist conditions (Aaltonen et al. 2013). However, the time lag between concentrations deeper in the soil and the flux measured above the humus layer make it difficult to compare the concentrations with the fluxes. Temperature and moisture conditions are also probably different between belowground and soil surface, which suggested that the effect of physico-chemical processes is different. 
The enclosure measurements have originally been developed for inert gases and significantly larger fluxes (e.g. for $\mathrm{CO}_{2}$ or $\mathrm{CH}_{4}$ ). The dynamic chamber method is commonly used for trace gas measurements, but has also been used previously for VOCs reliably using VOC-free air as a supply air (see e.g. Hakola et al. 2006; Hellén et al. 2006; Tiiva et al. 2007; Aaltonen et al. 2011; Faubert et al. 2010; Mäki et al. 2017). Frequently, MnO2-scrubber and active carbon filters are used between the supply air pump and the chamber to filter the air that is pumped into the chamber headspace. With concentrations that are often close to detection limits of the instruments, the most important requirements for the supply air is a stable concentration with a steady flow rate. Employment of dynamic chambers to measure trace gas fluxes is considered as a reliable method, the problems related to changes in concentration gradient between the soil and the atmosphere may be reduced with this technique. The fluxes are determined from the concentrations of incoming and outgoing air flows during the chamber closure and calculated using mass balance equations, which takes into account the possible change in the concentration inside the chamber headspace. The dynamic enclosure method was previously tested in field conditions using standard gas with known VOC concentrations and quadrupole-PTR-MS (Kolari et al. 2012). The chamber system used in the current study underestimates the artificially generated VOC flux rates at varying degrees: for isoprene, monoterpene and many oxygenated VOCs the underestimation is 5$30 \%$ (Kolari et al. 2012). Deposition of water soluble VOCs on moist leaf and soil surfaces and chamber walls is a bias in chamber flux measurements, but surprisingly also poorly water soluble monoterpenes from the forest floor were affected by the relative humidity of the chamber (Mäki et al. 2019).

Very high spatial variation in forest floor BVOC fluxes at the SMEAR II stand was reported by Aaltonen et al. (2011, 2013). Spatial variation of forest floor BVOC fluxes was likely created by varying vegetation cover and temperature (Mäki et al. 2019). This underlines the importance of having a sufficient number of parallel sampling points. Despite the high spatial variability in forest floor BVOC fluxes, no significant differences in individual isoprenoid concentrations were found between each soil pit, which were compared among the soil horizons.
Seasonal and inter-annual variation

The three-year measurements of the 2009-2011 period indicated noteworthy concentrations of isoprenoids in the belowground horizons that were similar in magnitude to reported aboveground concentrations. The following aboveground concentration ranges were obtained: $\alpha$-pinene $\left(0.2-6.3 \mu \mathrm{g} \mathrm{m}^{-3}\right), \Delta$-3-carene $(0.1-$ $\left.2.5 \mu \mathrm{g} \mathrm{m}^{-3}\right), \beta$-pinene $\left(0.04-0.3 \mu \mathrm{g} \mathrm{m}^{-3}\right)$, and camphene $\left(0.02-0.3 \mu \mathrm{g} \mathrm{m}^{-3}\right)$ in the same boreal coniferous forest by Hakola et al. (2009). Soil VOC concentrations are not directly comparable with air concentrations, because the soil air volume is concentrated only within soil pores. The seasonal variation in the belowground isoprenoid concentrations was less clear than previously observed in isoprenoid fluxes sampled from the forest floor (Aaltonen et al. 2011, 2013; Mäki et al. 2017, 2019). It is difficult to make comparisons between the campaigns one and two, when VOC concentrations measurements were carried out using two different measurement pits. The timing of the high monoterpene concentrations in the O- and B-horizons in June and July also differs from the peaks in forest floor monoterpene fluxes, which are typically observed in spring, early summer and in October (Hellén et al. 2006; Aaltonen et al. 2011, 2013; Mäki et al. 2017, 2019). High soil water content in spring slows down the diffusion and could also cause isoprenoid accumulation in the soil. Isoprene was not consistently observed and its highest concentrations were always obtained during the autumn, not during the season of active shoot growth. VOC concentration measurements were conducted in the different gas collectors during the first measurement 2008-2011 and the second (2016) measurement campaigns. The experimental variables that changed in this study were structure, installation and the length of the recovery time between installation and measurements. Changes in any of these variables may have influenced the VOC concentrations between the two campaign periods. The period between installation and first sampling was as short as six months in 2008, but by 2009 it was 11 months. Some roots were likely cut during installation, but the period between installation and first sampling decreases a risk of disturbance for the VOC concentration measurements. The period between installation and first sampling was as long as five years by the time the second campaign was implemented.

During the second campaign, the measurements indicated noteworthy concentrations of isoprenoids 
belowground throughout the year. Soil concentrations and forest floor fluxes of sesquiterpenes were relatively high during spring, which was contrary to the findings of two earlier studies that reported the branch measurements of sesquiterpene fluxes mainly occurred in midsummer (Tarvainen et al. 2005; Hakola et al. 2006). Sesquiterpenes in soil may originate from vegetation and decomposition processes with decaying substrates. Belowground monoterpene concentrations varied seasonally and had high concentrations in late summer, in October, and in December. High concentrations in October are in agreement with observations of the timing of isoprenoid fluxes from the forest floor reported in other studies (Hellén et al. 2006; Aaltonen et al. 2011, 2013; Mäki et al. 2017). Our results indicate that isoprenoid production is not limited to the maximum litter production period in autumn, but that the O-horizon is a relatively active VOC source during the whole snow free period. Decomposition processes slowly released isoprenoids from needle storage (Kainulainen and Holopainen 2002). Vegetation drops small amounts of litter year-round, thus litter is a continuous and renewable VOC source on the soil surface. The low seasonal variation in monoterpene concentrations in deeper mineral soils compared to the O-horizon and the A-horizon may be related to differences in source abundance between vertical soil horizons. The VOCs may also be captured in soils through adsorption on clay minerals (Deng et al. 2017), which means that VOCs are not released into the atmosphere.

We also measured the soil isoprenoid concentrations on one occasion during the snow cover period. It is likely that the relatively high concentrations of VOCs in the O-horizon in wintertime are related to physical characteristics of the snowpack. The snowpack has icy layers and low temperatures; characteristics that render it relatively impermeable and thus hinder the diffusion of VOCs. Such a reduction in diffusion would result in the accumulation of VOCs at the snow-soil interface and also within the surface layers of soil itself. Aaltonen et al. (2012) measured both monoterpene (0.4$\left.6.2 \mu \mathrm{g} \mathrm{m}^{-3}\right)$ and sesquiterpene $\left(0.08-1.0 \mu \mathrm{g} \mathrm{m}^{-3}\right)$ concentrations inside the snowpack, and showed that the concentrations were generally higher close to the soil surface and lower just next to the snowpack-air interface. We found that the wintertime monoterpene concentrations in the O-horizon were high, and were the same order of magnitude as those reported inside snowpack during winters (Aaltonen et al. 2012). Microbial activity may lead to VOC production in the snowpack close to the soil surface (Liptzin et al. 2015).

The period of snow cover may be shortened due to climate warming which could lead to an increase in VOC fluxes from boreal soils, because microbial activity also occurs in low temperatures. If air temperatures will increase and snow melts earlier, it could also increase VOC production and fluxes from the O-horizon though microbial decomposition and metabolism, when radiation warms the dark soil surface. Alternatively, activity might be reduced because of waterlogging in warmer and wetter winters, which could make snow cover less permeable (Aaltonen et al. 2012). The water-soluble VOCs may also be sequestered by wet snow. Instead, VOCs would probably be released into the atmosphere in spring after snow melt. Chamber flux measurements showed that some VOCs are released through the soil surface and snowpack into the atmosphere in December during continuous snow cover, which indicates that soil and snowpack are VOC sources or storages during wintertime. So far, there are only a very small number of other studies that have measured or estimated VOC fluxes during wintertime and more research is needed to relate soil VOCs to microbial processes (Aaltonen et al. 2012; Liptzin et al. 2015).

\section{Conclusions}

Boreal forest soil contains a large number of VOCs and the concentrations differ in regard to soil depth. Dominating monoterpene concentrations are comparable to the air concentrations above a coniferous forest soil, which emphasizes the role of soil processes as source for VOCs to the canopy space. Monoterpene concentrations vary seasonally in surface layers, this likely reflects the sources that are changing seasonally with the litterfall and biological activity, but also physical factors like temperature, soil moisture and the presence or absence of snow is also important. The measurement procedures include uncertainties that were discussed in detailed. Belowground VOC concentrations measured by this method are likely underestimations and these results should be taken as order of magnitude estimates rather than precise values of the soil VOC concentrations. Methodological developments are required in the future, to estimate concentrations of highly reactive compounds from soils in situ. However, this is a first 
study where belowground VOC concentrations were quantified in situ, and for this reason, this study provides valuable insights to the VOC sources present in soils. An improved process understanding of the sources is required for making forecasts of possible climate change effects on VOC exchange from ecosystems, and this work has contributed to our understanding on the soil as source for VOCs.

Acknowledgements We would like to thank the staff of the SMEAR II and Hyytiälä Forestry Field station for their help and for use of the facilities in making this study. We gratefully acknowledge the financial support by the Jenny and Antti Wihuri Foundation, the Academy of Finland Centre of Excellence programme (project no 272041) and the Academy of Finland project 130984 and 286685 are also gratefully acknowledged.

Author contributions Manuscript preparation and analyzing results (M.M. and H.A.). All authors contributed to the experimental planning, the discussion of the results and the writing on the manuscript.

Funding Information Open access funding provided by University of Helsinki including Helsinki University Central Hospital.

Data availability Mäki, Mari (2017), "Data for the manuscript", Mendeley Data. https://doi.org/10.17632/dn2rj3yf9p.1

\section{Compliance with ethical standards}

Disclaimer The authors affirm that this study is an original contribution and has not been submitted elsewhere. The authors declare no competing financial interests.

Open Access This article is distributed under the terms of the Creative Commons Attribution 4.0 International License (http:// creativecommons.org/licenses/by/4.0/), which permits unrestricted use, distribution, and reproduction in any medium, provided you give appropriate credit to the original author(s) and the source, provide a link to the Creative Commons license, and indicate if changes were made.

\section{References}

Aaltonen H, Pumpanen J, Pihlatie M, Hakola H, Hellén H, Kulmala L, Vesala T, Bäck J (2011) Boreal pine forest floor biogenic volatile organic compound fluxes peak in early summer and autumn. Agric For Meteorol 151:682-691. https://doi.org/10.1016/j.agrformet.2010.12.010

Aaltonen H, Pumpanen J, Hakola H, Vesala T, Rasmus S, Bäck J (2012) Snowpack concentrations and estimated fluxes of volatile organic compounds in a boreal forest. Biogeosciences 9(6):2033-2044. https://doi.org/10.5194/bg9-2033-2012

Aaltonen H, Aalto J, Kolari P, Pihlatie M, Pumpanen J, Kulmala M, Nikinmaa E, Vesala T, Bäck J (2013) Continuous VOC flux measurements on boreal forest floor. Plant Soil 369:241256. https://doi.org/10.1007/s11104-012-1553-4

Alexander M (1977) Introduction to soil microbiology, 2nd edn. Wiley, New York, p 467

Asensio D, Peñuelas J, Filella I, Llusià J (2007a) On-line screening of soil VOCs exchange responses to moisture, temperature and root presence. Plant Soil 291(1-2):249-261. https://doi. org/10.1007/s11104-006-9190-4

Asensio D, Peñuelas J, Llusià J, Ogaya R, Filella I (2007b) Interannual and interseasonal soil $\mathrm{CO}_{2}$ efflux and $\mathrm{VOC}$ exchange rates in a Mediterranean holm oak forest in response to experimental drought. Soil Biol Biochem 39:2471-2484. https://doi.org/10.1016/j.soilbio.2007.04.019

Asensio D, Peñuelas J, Prieto P, Estiarte M, Filella I, Llusià J (2008a) Interannual and seasonal changes in the soil exchange rates of monoterpenes and other VOCs in a Mediterranean shrubland. Eur J Soil Sci 59(5):878-891. https://doi.org/10.1111/j.1365-2389.2008.01057.x

Asensio D, Owen SM, Llusià J, Peñuelas J (2008b) The distribution of volatile isoprenoids in the soil horizons around Pinus halepensis trees. Soil Biol Biochem 40:2937e2947

Asensio D, Yuste JC, Mattana S, Ribas À, Llusià J, Peñuelas J (2012) Litter VOCs induce changes in soil microbial biomass $\mathrm{C}$ and $\mathrm{N}$ and largely increase soil $\mathrm{CO} 2$ efflux. Plant Soil 360(1-2):163-174. https://doi.org/10.1007 /s11104-012-1220-9

Bäck J, Aaltonen H, Hellén H, Kajos MK, Patokoski J, Taipale R, Pumpanen J, Heinonsalo J (2010) Variable fluxes of microbial volatile organic compounds (MVOCs) from rootassociated fungi isolated from scots pine. Atmos Environ 44(30):3651-3659. https://doi.org/10.1016/j. atmosenv.2010.06.042

Beyer L (1996) Soil organic matter composition of spodic horizons in Podzols of the northwest German lower plain. Sci Total Environ 181(2):167-180. https://doi.org/10.1016 /0048-9697(95)05007-8

Bourtsoukidis E, Behrendt T, Yañez-Serrano AM, Hellén H, Diamantopoulos E, Catão E, Ashworth K, Pozzer A, Quesada CA, Martins DL, Sá M, Araujo A, Brito J, Artaxo P, Kesselmeier J, Lelieveld J, Williams J (2018) Strong sesquiterpene emissions from Amazonian soils. Nat Commun 9:2226. https://doi.org/10.1038/s41467018-04658-y

Davidson EA, Janssens IA (2006) Temperature sensitivity of soil carbon decomposition and feedbacks to climate change. Nature 440(7081):165-173. https://doi.org/10.1038 /nature 04514

Deluca TH, Boisvenue C (2012) Boreal forest soil carbon: distribution, function and modelling. Forestry 85(2):161-184. https://doi.org/10.1093/forestry/cps003

Delwiche CF, Sharkey TD (1993) Rapid appearance of 13C in biogenic isoprene when $13 \mathrm{CO}_{2}$ is fed to intact leaves. Plant Cell Environ 16:587-591. https://doi.org/10.1111/j.13653040.1993.tb00907.x

Deng L, Yuan P, Liu D, Annabi-Bergaya F, Zhou J, Chen F, Liu Z (2017) Effects of microstructure of clay minerals, 
montmorillonite, kaolinite and halloysite, on their benzene adsorption behaviors. Appl Clay Sci 143:184-191. https://doi.org/10.1016/j.clay.2017.03.035

Ditengou FA, Müller A, Rosenkranz M, Felten J, Lasok H, van Doorn MM, Legue V, Palme K, Schnitzler JP, Polle A (2015) Volatile signalling by sesquiterpenes from ectomycorrhizal fungi reprogrammes root architecture. Nat Commun 6:6279. https://doi.org/10.1038/ncomms 7279

FAO-Unesco, ISRTC (1990) Soil map of the world Revised legend Reprinted with corrections World Soil Resources Report 60

Faubert P, Tiiva P, Rinnan Å, Michelsen A, Holopainen JK, Rinnan R (2010) Doubled volatile organic compound emissions from subarctic tundra under simulated climate warming. New Phytol 187(1):199-208. https://doi. org/10.1111/j.1469-8137.2010.03270.x

Faubert P, Tiiva P, Michelsen A, Rinnan Å, Ro-Poulsen H, Rinnan $R$ (2012) The shift in plant species composition in a subarctic mountain birch forest floor due to climate change would modify the biogenic volatile organic compound emission profile. Plant Soil 352(1-2):199-215. https://doi. org/10.1007/s11104-011-0989-2

Fierer N, Schimel JP, Holden PA (2003) Variations in microbial community composition through two soil depth profiles. Soil Biol Biochem 35:167-176. https://doi.org/10.1016/S00380717(02)00251-1

Gray CM, Monson RK, Fierer N (2010) Emissions of volatile organic compounds during the decomposition of plant litter. $\mathrm{J}$ Geophys Res 115:G03015. https://doi.org/10.1029/2010 JG001291

Greenberg JP, Asensio D, Turnipseed A, Guenther AB, Karl T, Gochis D (2012) Contribution of leaf and needle litter to whole ecosystem VOC fluxes. Atmos Environ 59:302-311. https://doi.org/10.1016/j.atmosenv.2012.04.038

Hakola H, Tarvainen V, Bäck J, Ranta H, Bonn B, Rinne J, Kulmala M (2006) Seasonal variation of mono- and sesquiterpene emission rates of scots pine. Biogeosciences 3:93101. https://doi.org/10.5194/bg-3-93-2006

Hakola H, Hellén H, Tarvainen V, Bäck J, Patokoski J, Rinne J (2009) Annual variations of atmospheric VOC concentrations in a boreal forest. Boreal Environ Res 14(4):722-730

Hari P, Kulmala M (2005) Station for measuring ecosystematmosphere relations (SMEAR II). Boreal Environ Res 10: 315-322

Hayward S, Muncey RJ, James AE, Halsall CJ, Hewitt CN (2001) Monoterpene emissions from soil in a Sitka spruce forest. Atmos Environ 35:4081-4087. https://doi.org/10.1016 /S1352-2310(01)00213-8

Hellén H, Hakola H, Laurila T, Hiltunen V, Koskentalo T (2002) Aromatic hydrocarbon and methyl tert-butyl ether measurements in ambient air of Helsinki (Finland) using diffusive samplers. Sci Total Environ 298(1-3):55-64. https://doi. org/10.1016/S0048-9697(02)00168-7

Hellén H, Hakola H, Pystynen KH, Rinne J, Haapanala S (2006) $\mathrm{C}_{2}-\mathrm{C}_{10}$ hydrocarbon emissions from a boreal wetland and forest floor. Biogeosciences 3:167-174. https://doi. org/10.5194/bg-3-167-2006

Hewitt CN, Street RA (1992) A qualitative assessment of the emission of non-methane hydrocarbon compounds from the biosphere to the atmosphere in the UK: present knowledge and uncertainties. Atmos Environ Part A
General Topics 26(17):3069-3077. https://doi. org/10.1016/0960-1686(92)90463-U

Högberg MN, Högberg P, Myrold DD (2007) Is microbial community composition in boreal forest soils determined by $\mathrm{pH}$, C-to-N ratio, the trees, or all three? Oecologia 150(4):590 601. https://doi.org/10.1007/s00442-006-0562-5

Ilvesniem H, Pumpanen J, Duursma R, Hari P, KeronenP KP, Kulmala M, Mammarella I, Nikinmaa E, Rannie U, Pohja T, Siivola E, Vesala T (2010) Water balance of a boreal scots pine forest. Boreal Environ Res 15:375-396

Ilvesniemi H, Liu C (2001) Biomass distribution in a young scots pine stand. Boreal Environ Res 6(1):3-8

Ilvesniemi H, Levula J, Ojansuu R, Kolari P, Kulmala L, Pumpanen J, Launiainen S, Vesala T, Nikinmaa E (2009) Long-term measurements of the carbon balance of a boreal scots pine dominated forest ecosystem. Boreal Environ Res 14:731-753

Insam H, Seewald M (2010) Volatile organic compounds (VOCs) in soils. Biol Fertil Soils 46:199-213. https://doi.org/10.1007 /s00374-010-0442-3

Isidorov V, Jdanova M (2002) Volatile organic compounds from leaves litter. Chemosphere 48:975-979. https://doi. org/10.1016/S0045-6535(02)00074-7

Isidorov VA, Smolewska M, Purzynska-Pugacewicz A, Tyszkiewicz Z (2010) Chemical composition of volatile and extractive compounds of pine and spruce leaf litter in the initial stages of decomposition. Biogeosciences 7:27852794. https://doi.org/10.5194/bg-7-2785-2010

Jacob DJ, Field BD, Li Q, Blake DR, de Gouw J, Warneke C, Hansel A, Wisthaler A, Singh HB, Guenther A (2005) Global budget of methanol: constraints from atmospheric observations. J Geophys Res 110:D08303. https://doi.org/10.1029 /2004JD005172

Kainulainen P, Holopainen JK (2002) Concentrations of secondary compounds in scots pine needles at different stages of decomposition. Soil Biol Biochem 34(1):37-42. https://doi. org/10.1016/S0038-0717(01)00147-X

Kolari P, KuImaIa L, Pumpanen J, Launiainen S, Ilvesniemi $\mathrm{H}$, Han P, Nikinmaa E (2009) $\mathrm{CO}_{2}$ exchange and component $\mathrm{CO} 2$ fluxes of a boreal scots pine forest. Boreal Environ Res 14(4)

Kolari P, Bäck J, Taipale R, Ruuskanen TM, Kajos MK, Rinne J, Kulmala M, Hari P (2012) Evaluation of accuracy in measurements of VOC emissions with dynamic chamber system. Atmos Environ 62:344-351. https://doi.org/10.1016/j. atmosenv.2012.08.054

Köster K, Berninger F, Lindén A, Köster E, Pumpanen J (2014) Recovery in fungal biomass is related to decrease in soil organic matter turnover time in a boreal fire chronosequence. Geoderma 235:74-82. https://doi.org/10.1016/j. geoderma.2014.07.001

Kramshøj M, Vedel-Petersen I, Schollert M, Rinnan A,, Nymand J, Ro-Poulsen H, Rinnan R (2016) Large increases in Arctic biogenic volatile emissions are a direct effect of warming. Nat Geosci 9:349-352. https://doi.org/10.1038/ngeo2692

Leff JW, Fierer N (2008) Volatile organic compound (VOC) emissions from soil and litter samples. Soil Biol Biochem 40(7): 1629-1636. https://doi.org/10.1016/j. soilbio.2008.01.018 
Lin C, Owen SM, Peñuelas J (2007) Volatile organic compounds in the roots and rhizosphere of Pinus spp. Soil Biol Biochem 39:951-960. https://doi.org/10.1016/j.soilbio.2006.11.007

Liptzin D, Helmig D, Schmidt SK, Seok B, Williams MW (2015) Winter gas exchange between the atmosphere and snowcovered soils on Niwot ridge, Colorado, USA. Plant Ecology \& Diversity 8(5-6):677-688. https://doi. org/10.1080/17550874.2015.1065925

Mäki M, Heinonsalo J, Hellén H, Bäck J (2017) Contribution of understorey vegetation and soil processes to boreal forest isoprenoid exchange. Biogeosciences 14(5):1055-1073. https://doi.org/10.5194/bg-14-1055-2017

Mäki M, Aalto J, Hellén H, Pihlatie M, Bäck J (2019) Interannual and seasonal dynamics of volatile organic compound fluxes from the boreal Forest floor. Front Plant Sci 10:191. https://doi.org/10.3389/fpls.2019.00191

Makkonen K, Helmisaari HS (1998) Seasonal and yearly variations of fine-root biomass and necromass in a scots pine (Pinus sylvestris L.) stand. For Ecol Manag 102:283-290. https://doi.org/10.1016/S0378-1127(97)00169-2

Mancuso S, Taiti C, Bazihizina N, Costa C, Menesatti P, Giagnoni L, Arenella M, Nannipieri P, Renella G (2015) Soil volatile analysis by proton transfer reaction-time of flight mass spectrometry (PTR-TOF-MS). Appl Soil Ecol 86:182-191. https://doi.org/10.1016/j.apsoil.2014.10.018

Monson RK, Fall R (1989) Isoprene emissions from Aspen leaves. Influence of environment and relation to photosynthesis and photorespiration. Plant Physiol 90(1):267-274. https://doi. org/10.1104/pp.90.1.267

Müller A, Faubert P, Hagen M, Castell W, Polle A, Schnitzler JP, Rosenkranz M (2013) Volatile profiles of fungi Chemotyping of species and ecological functions. Fungal Genet Biol 54:25-33. https://doi.org/10.1016/j. fgb.2013.02.005

Ortega J, Helmig D (2008) Approaches for quantifying reactive and low volatility biogenic organic compound emissions by vegetation enclosure techniques - part A. Chemosphere 72: 365-380. https://doi.org/10.1016/j.chemosphere.2007. 11.020

Parmelee RW, Ehrenfeld JG, Tate RL (1993) Effects of pine roots on microorganisms, fauna, and nitrogen availability in two soil horizons of a coniferous forest spodosol. Biol Fertil Soils 15(2):113-119. https://doi.org/10.1007/BF00336428

Peñuelas J, Staudt M (2010) BVOCs and global change. Trends Plant Sci 15(3):133-144. https://doi.org/10.1016/j. tplants.2009.12.005

Peñuelas J, Asensio D, Tholl D, Wenke K, Rosenkranz M, Piechulla B, Schnitzler JP (2014) Biogenic volatile emissions from the soil. Plant Cell Environ 37(8):1866-1891. https://doi.org/10.1111/pce.12340

Pihlatie M, Pumpanen J, Rinne J, Ilvesniemi H, Simojoki A, Hari P, Vesala T (2007) Gas concentration driven fluxes of nitrous oxide and carbon dioxide in boreal forest soil. Tellus 59B: 458-469. https://doi.org/10.1111/j.1600-0889.2007.00278.x

Pirinen P, Simola H, Aalto J, Kaukoranta JP, Karlsson P, Ruuhela R (2012) Climatological statistics of Finland 1981-2010. Finnish Meteorological Institute, Helsinki

Prescott CE (2010) Litter decomposition: what controls it and how can we alter it to sequester more carbon in forest soils? Biogeochemistry 101(1-3):133-149. https://doi. org/10.1007/s10533-010-9439-0
Prescott CE, Maynard DG, Laiho R (2000) Humus in northern forests: friend or foe? For Ecol Manag 133(1):23-36. https://doi.org/10.1016/S0378-1127(99)00295-9

Pumpanen J, Ilvesniemi H, Kulmala L, Siivola E, Laakso H, Kolari P, Helenelund C, Laakso M, Uusimaa M, Hari P (2008) Respiration in boreal forest soil as determined from carbon dioxide concentration profile. Soil Sci Soc Am J 72: 1187-1196. https://doi.org/10.2136/sssaj2007.0199

Pumpanen J, Kulmala L, Lindén A, Kolari P, Nikinmaa E, Hari P (2015) Seasonal dynamics of autotrophic respiration in boreal forest soil estimated from continuous chambermeasurements. Boreal Environ Res 20:637-650

Rinnan R, Gierth D, Bilde M, Rosenørn T, Michelsen A (2014) Off-season biogenic volatile organic compound emissions from heath mesocosms: responses to vegetation cutting. The Microbial Regulation of Global Biogeochemical Cycles 160. https://doi.org/10.3389/fmicb.2013.00224

Rösecke J, Pietsch M, König WA (2000) Volatile constituents of wood-rotting basidiomycetes. Phytochemistry 54(8):747750. https://doi.org/10.1016/S0031-9422(00)00138-2

Rossabi S, Choudoir M, Helmig D, Hueber J, Fierer N (2018) Volatile organic compound emissions from soil following wetting events. J Geophys Res, Biogeosci 123(6):19882001. https://doi.org/10.1029/2018JG004514

Schenkel D, Maciá-Vicente JG, Bissell A, Splivallo R (2018) Fungi indirectly affect plant root architecture by modulating soil volatile organic compounds. Front Microbiol 9. https://doi.org/10.3389/fmicb.2018.01847

Schulz S, Dickschat JS (2007) Bacterial volatiles: the smell of small organisms. Nat Prod Rep 24:814-842

Sharkey TD, Singsaas EL (1995) Why plants emit isoprene? Nature 374:769. https://doi.org/10.1038/374769a0

Skopp J, Jawson MD, Doran JW (1990) Steady-state aerobic microbial activity as a function of soil-water content. Soil Sci Soc Am J 54:1619-1625. https://doi.org/10.2136 /sssaj1990.03615995005400060018x

Smolander A, Ketola RA, Kotiaho T, Kanerva S, Suominen K, Kitunen V (2006) Volatile monoterpenes in soil atmosphere under birch and conifers: effects on soil $\mathrm{N}$ transformations. Soil Biol Biochem 38:3436-3442. https://doi.org/10.1016/j. soilbio.2006.05.019

Svendsen SH, Lindwall F, Michelsen A, Rinnan R (2016) Biogenic volatile organic compound emissions along a high arctic soil moisture gradient. Sci Total Environ 573:131-138. https://doi.org/10.1016/j.scitotenv.2016.08.100

Svendsen SH, Prieméa A, Voriskovab J, Kramshøja M, Schostaga M, Jacobsen CS, Rinnan R (2018) Emissions of biogenic volatile organic compounds from arctic shrub litter are coupled with changes in the bacterial community composition. Soil Biol Biochem 120:80-90. https://doi.org/10.1016/j. soilbio.2018.02.001

Tahir HA, Gu Q, Wu H, Raza W, Hanif A, Wu L, Colman MV, Gao X (2017) Plant growth promotion by volatile organic compounds produced by Bacillus subtilis SYST2. Front Microbiol 8:171. https://doi.org/10.3389/fmicb.2017.00171

Tarvainen V, Hakola H, Hellén H, Bäck J, Hari P, Kulmala M (2005) Temperature and light dependence of the VOC emissions of scots pine. Atmos Chem Phys 5:989-998. https://doi.org/10.5194/acp-5-989-2005

Taylor JP, Wilson B, Mills MS, Burns RG (2002) Comparison of microbial numbers and enzymatic activities in surface soils 
and subsoils using various techniques. Soil Biol Biochem 34: 387-401. https://doi.org/10.1016/S0038-0717(01)00199-7

Tholl D, Boland W, Hansel A, Loreto F, Röse USR, Schnitzler JP (2006) Practical approaches to plant volatile analysis. Plant J 45:540-560. https://doi.org/10.1111/j.1365-313 X.2005.02612.x

Tiiva P, Rinnan R, Faubert P, Räsänen J, Holopainen T, Kyrö E, Holopainen JK (2007) Isoprene emission from a subarctic peatland under enhanced UV-B radiation. New Phytol 176: 346-355

Timonen S, Sinkko H, Sun H, Sietiö OM, Rinta-Kanto JM, Kiheri H, Heinonsalo J (2017) Ericoid roots and mycospheres govern plant-specific bacterial communities in boreal forest humus. Microb Ecol 73:1-15. https://doi.org/10.1007/s00248016-0922-6

Veres PR, Behrendt T, Klapthor A, Meixner FX, Williams J (2014) Volatile organic compound emissions from soil: using proton-transfer-reaction time-of-flight mass spectrometry (PTR-TOF-MS) for the real time observation of microbial processes. Biogeosci Discuss 11:12009-12038. https://doi. org/10.5194/bgd-11-12009-2014

Weikl F, Ghirardo A, Schnitzler JP, Pritsch K (2016) Sesquiterpene emissions from Alternaria alternata and Fusarium oxysporum: effects of age, nutrient availability, and co-cultivation. Nat Sci Rep 6. https://doi.org/10.1038/srep22152

Wenke K, Kai M, Piechulla B (2010) Belowground volatiles facilitate interactions between plant roots and soil organisms. Planta 231:499-506. https://doi.org/10.1007 /s00425-009-1076-2

Yamanaka K, Reynolds KA, Kersten RD, Ryan KS, Gonzalez DJ, Nizet V, Dorrestein PC, Moore BS (2015) Terpene synthases are widely distributed in bacteria. Proceedings of the National Academy of Sciences of the United States of America, 111: 1957-1962. https://doi.org/10.1073/pnas.1422108112

Zhong L, Cantrell K, Mitroshkov A, Shewell J (2014) Mobilization and transport of organic compounds from reservoir rock and caprock in geological carbon sequestration sites. Environ Earth Sci 71(9):4261-4272. https://doi. org/10.1007/s12665-013-2823-Z

Ziemann PJ, Atkinson R (2012) Kinetics, products, and mechanisms of secondary organic aerosol formation. Chem Soc Rev 41:6582-6605. https://doi.org/10.1039/c2cs35122f

Publisher's note Springer Nature remains neutral with regard to jurisdictional claims in published maps and institutional affiliations. 